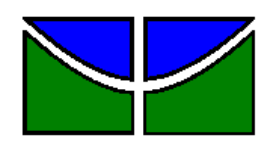

Universidade de Brasília

Faculdade de Economia, Administração, Contabilidade e Departamento de Administração

Curso de Graduação em Administração à Distância

NÁDIA SANT'ANNA BRANCO

VIDA PESSOAL X VIDA PROFISSIONAL: o caminho para o equilíbrio

Brasília - DF 


\section{VIDA PESSOAL X VIDA PROFISSIONAL: o caminho para o equilíbrio}

Monografia apresentada à Universidade de Brasília (UnB) como requisito parcial para obtenção do grau de Bacharel em Administração.

Professor Supervisor: Professor Dr. Antônio Isidro Filho

Brasília - DF 


\section{Branco, Nádia Sant'Anna}

Vida Pessoal x Vida Profissional: o caminho para o equilíbrio / Nádia Sant' Anna Branco. - Brasília, 2010.

83 f.: il.

Monografia (bacharelado) - Universidade de Brasília, Departamento de Administração - EaD, 2010.

Orientador: Prof. Dr. Antônio Isidro Filho, Departamento de Administração.

1. O Mercado de Trabalho. 2. Os Papéis na vida do Indivíduo. 3. O Papel da Mulher na Sociedade. I. Título. II. Brasília-Faculdade de Economia, Administração, Contabilidade e Departamento de Administração. Curso de Graduação à Distância. 


\title{
VIDA PESSOAL X VIDA PROFISSIONAL: O caminho para o equilíbrio
}

\begin{abstract}
A Comissão Examinadora, abaixo identificada, aprova o Trabalho de Conclusão do Curso de Administração da Universidade de Brasília da aluna
\end{abstract}

\section{Nádia Sant'Anna Branco}

Prof. Dr. Antônio Isidro Filho

Professor-Orientador

Prof. Dr. Antônio Isidro Filho

Professor-Examinador
Prof ${ }^{a}$ Késia Rozzett

Professor-Examinador

Brasília, 04 de Dezembro de 2010. 
Dedico esse trabalho aos meus pais e meu filho, amores da minha vida e meu porto seguro. 


\section{AGRADECIMENTOS}

É preciso lembrar que, durante todo esse tempo, não andei sozinha. Contei com o apoio, além da minha família, de muitas pessoas que foram presenças fundamentais, onde cada participação se tornou importante.

Em primeiro lugar, agradeço a Deus que me deu forças e iluminou meus pensamentos com Seu infinito amor e sabedoria.

Agradeço aos meus amados pais, Custódio e Marianna, que por toda a vida me ajudaram e torceram por mim, me lembrando do significado da palavra "perseverança" e, com todo o seu amor e carinho, proporcionaram uma travessia tranquila durante os meus estudos.

Ao meu filho Henrique que, nas horas mais difíceis, teve a paciência de me ensinar e orientar, estando sempre ao meu lado. Aos meus irmãos, cunhadas e sobrinhos que, à sua maneira, deram-me apoio e incentivo.

Ao querido Fernando que, com sua força e paciência, ajudou-me nos estudos e pesquisas, encontrando, sempre, tempo em seu dia atribulado.

A todos os professores que compartilharam seus conhecimentos e me orientaram ao encontro do aprendizado. Em especial à professora Alice Damasceno que, além de professora, tornou-se uma amiga muito querida.

À professora Maira Pinto Cauchioli Rodrigues, orientadora e amiga, pelo apoio e colaboração em todos os momentos da construção desse trabalho.

Aos meus queridos amigos Beké, Byron, Da. Odete, Edimara, Dimas, Rafael e Fabíola que me proporcionaram valiosos ensinamentos, demonstrando carinho e apoio na nossa convivência.

Aos companheiros e amigos do curso Cid, Dulce, Ana Goulart, Josele, Leila, Milson, Silvio, Murilo, Leonardo, Josiany, Nelson, Karen, Juliana, Thiago, Cláudia, Júlio e Sirlei, que levo em meu coração, pela amizade, respeito e apoio durante nossa jornada. Em especial ao Luis Augusto e Silvio Sznifer, pelo apoio e incentivo incondicionais.

A todos os participantes que, de alguma forma, permitiram a conclusão do presente trabalho.

Aos coordenadores, orientadores e funcionários da Universidade de Brasília e, em especial, ao professor Matias-Pereira pela sua grande força. 
"É preciso sentir a necessidade da experiência, da observação, ou seja, a necessidade de sair de nós próprios para acender à escola das coisas, se as queremos conhecer e compreender".

Émile Durkheim 


\section{RESUMO}

Esse trabalho buscou conhecer e entender questões geradoras de conflito e sua bidirecionalidade - família/trabalho e trabalho/família -, para o gênero feminino em uma instituição financeira. A presença feminina vem tendo destaque cada vez mais no mercado de trabalho, nas esferas públicas e privadas, em seus mais diversos setores produtivos. Assim, compreender a representatividade dessas duas dimensões pela visão de mulheres em cargo de chefia, e sua correlação com o conflito, se tornou importante para identificar o sofrimento e o prazer que elas [dimensões] despertam. Para tanto, entrevistaram-se seis mulheres gerentes que atuam em uma agência bancária em Brasília, cujas entrevistas foram gravadas e posteriormente transcritas para garantir a fidelidade do discurso. A partir da análise de conteúdo realizada, confirmou-se ser a família o centro da vida do indivíduo como determinante para o crescimento enquanto seres humanos. $O$ conflito foi descrito mais como uma questão a ser administrada e controlada, mesmo que seja constante nos seus cotidianos, principalmente em atividades profissionais, quando o trabalho é visto como necessário, trazendo o sentimento de utilidade e completude para a vida do indivíduo. Entendeu-se que não há uma "receita" para lidar com as interferências do conflito, sendo necessário buscar meios de administrá-lo. Tais meios podem incluir separar as duas esferas, com momentos próprios para cada uma delas, ajuda externa de profissionais, adaptações ou ajustes diários.

Palavras-chave: mulheres, vida pessoal e profissional; conflito. 


\section{LISTA DE QUADROS}

Quadro 1 - O Significado da Família, sua Base e Importância...................................36

Quadro 2 - O Trabalho: Significado e Representação na Vida do Indivíduo ..............44

Quadro 3 - O Conflito na Vida Profissional e nas Relações Familiares.......................53

Quadro 4 - Consequências dos Conflitos Experimentados pelas Gerentes ...............59 


\section{SUMÁRIO}

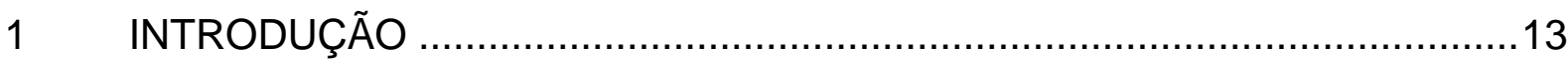

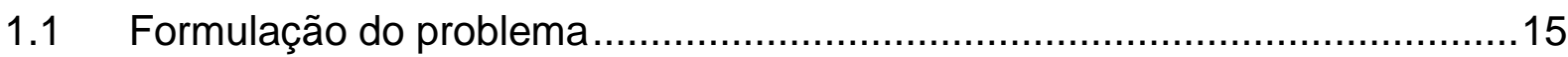

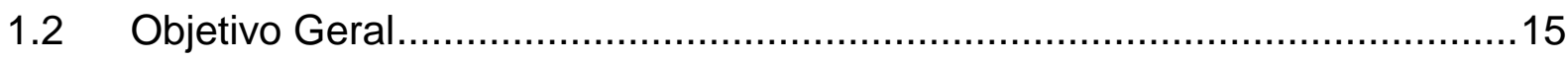

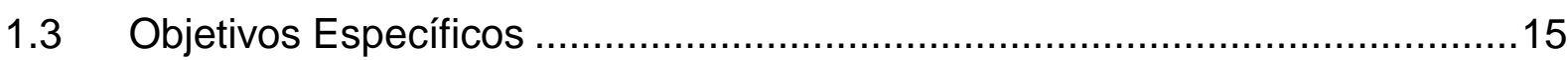

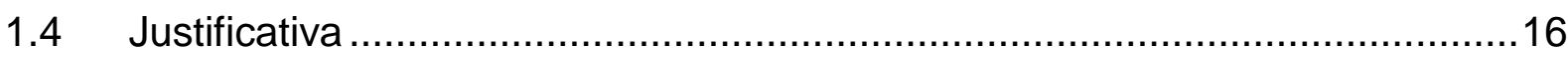

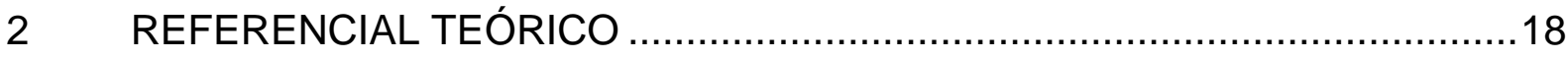

2.1 O Mercado de Trabalho: planejamento em curto prazo …….......................18

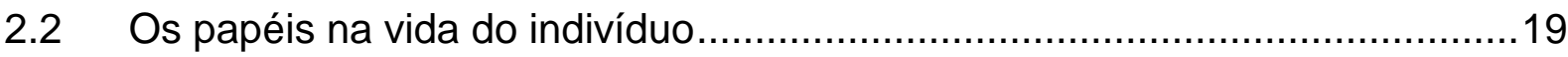

2.2.1 O Papel da Mulher na Sociedade ..............................................................

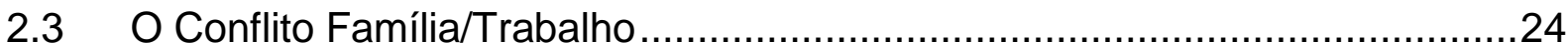

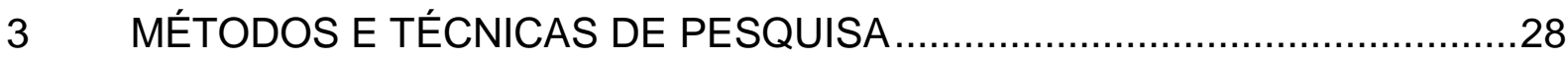

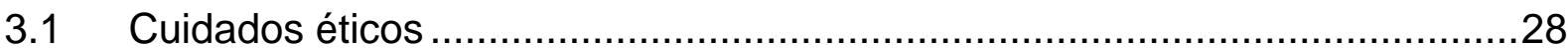

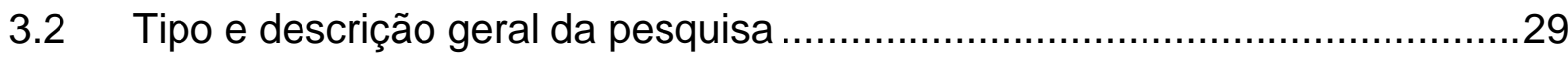

3.3 Caracterização da organização, setor ou área do objeto de estudo................30

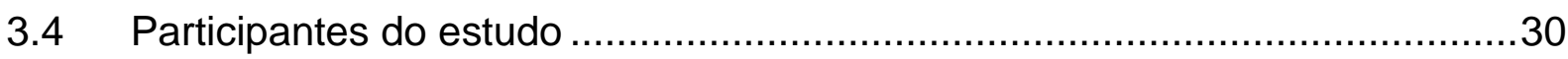

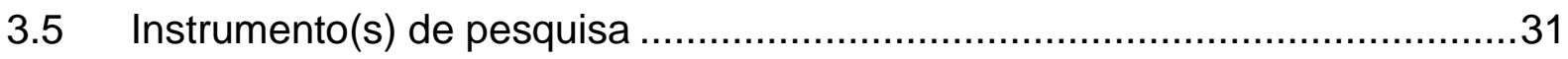

3.6 Procedimentos de coleta e de análise de dados .........................................33

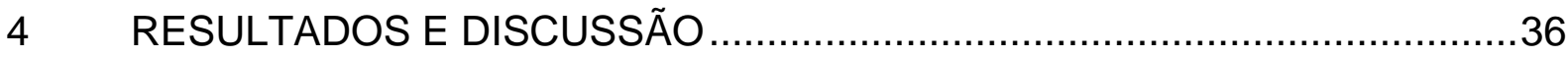

4.1 Conhecendo a realidade pessoal e profissional da participante do estudo ....36

4.1.1 Família simboliza apoio e formadora do caráter do indivíduo.........................37

4.1.2 A organização e a priorização são necessárias, mas nem sempre são conseguidas na forma em que se deseja.....

4.1.3 A qualidade do tempo dedicado à família não está atrelado à quantidade que se tem; ora essa quantidade faz a diferença.

4.1.4 No cotidiano, entre os múltiplos papéis desempenhados pelas mulheres todos encontram o seu lugar no devido tempo 
4.1.6 O trabalho: sinônimo de dignidade

4.1.7 As pressões diárias causam o sofrimento e o estresse ............................45

4.1.8 A capacitação é essencial para o crescimento profissional.

4.1.9 O diálogo se transforma na ponte para a integração social em qualquer ambiente, quando interferências podem comprometer o bom relacionamento

4.1.10 Ser reconhecida e aceita pode ser uma questão de foro íntimo

4.2 Descrevendo o conflito vivido

4.2.1 Entre os motivos do conflito, a diversidade existente na sociedade pode fazêlo emergir a qualquer momento

4.2.2 O conflito pode ser gerado, independente do outro, pela própria personalidade do individuo

4.3 Identificando as formas encontradas para lidar com o conflito

4.3.1 Para conseguir compatibilizar família e trabalho é fundamental manter-se um equilíbrio entre essas duas instâncias da vida

4.3.2 A dedicação ao trabalho é fator de privação ao convívio familiar, gerando cobrança pessoal

4.3.3 Dentre os meios para administrar o conflito, ainda é o diálogo a forma mais eficiente de mantê-lo sob controle, mesmo que outros ajustes e providências sejam necessários

5 CONCLUSÕES E RECOMENDAÇÕES

REFERÊNCIAS

APÊNDICES.

APÊNDICE 1 - CARTA DE APRESENTAÇÃO PARA A INSTITUIÇÃO BANCÁRIA71

APÊNDICE 2 - CARTA DE APRESENTAÇÃO PARA AS PARTICIPANTES DA PESQUISA.

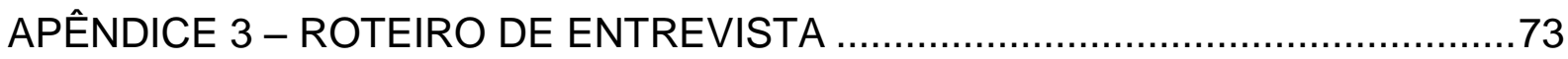

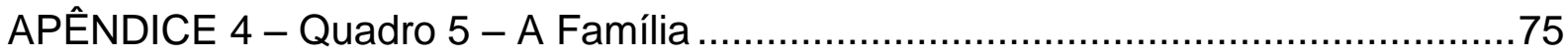

APÊNDICE 5 - Quadro 6 - Organização, Prioridades e a Qualidade do Tempo em Família

APÊNDICE 6 - Quadro 7 - A mãe, a mulher, interferências, apoio familiar e bemestar 
APÊNDICE 8 - Quadro 9 - A Capacitação Profissional e o Convívio Social no Trabalho

APÊNDICE 9 - Quadro 10 - Definição da Gerente, Reconhecimento e Interferências no Trabalho

APÊNDICE 10 - Quadro 11 - O Conflito .88

APÊNDICE 11 - Quadro 12 - O Conflito nas Relações Profissionais e Familiares ..90 APÊNDICE 12 - Quadro 13 - O Trabalho interferindo nas Relações Familiares .....92 APÊNDICE 13 - Quadro 14 - Satisfação Pessoal e Administração do Conflito .......94 


\section{INTRODUÇÃO}

Atualmente, através de literatura pertinente, percebe-se que não há mais separação entre a vida pessoal e a profissional do indivíduo, podendo constituir-se em uma das causas de seu sofrimento e estresse no dia-a-dia, impedindo a instalação do bem-estar no desenvolvimento profissional e nas relações familiares.

$\mathrm{O}$ avanço da tecnologia possibilita que o horário laboral se estenda por todo o dia do funcionário, independentemente da empresa e do ramo em que ela atua. Por esse motivo, pensa-se que deveria haver um hiato entre a vida pessoal e profissional do indivíduo para não se confundirem. Entende-se que a não percepção e a manutenção da tênue linha que as separa possa desencadear problemas pessoais e profissionais.

Considera-se a possibilidade de haver uma conciliação entre a vida pessoal e a profissional, permitindo, realmente, um maior bem-estar e uma melhor qualidade de vida. Entretanto, essa conciliação tem se mostrado irreal quando, a cada dia que passa, os notebooks e os celulares são companhias constantes na hora de lazer. Ou seja, o local de trabalho está em qualquer lugar onde esteja a pessoa.

Quando a carreira é apontada pelo indivíduo como eixo primordial de sua vida, ditando os valores pessoais, há uma constante busca por superação e, em razão dessa ambição, acaba por submeter-se a uma escravidão profissional (PAGÈS, 1987, citado por TOLEDO, 2006), sacrificando a vida pessoal para atingimento do sucesso profissional.

Para Durkheim (1979), esse fato social tem exercido sobre o indivíduo uma coerção exterior, que pode tornar seu cotidiano desgastante e sofrido. Para evitar esses efeitos danosos, vê-se como necessário que ocorra uma interação saudável entre os papéis assumidos pelo indivíduo, quando o tempo dedicado à família e ao desenvolvimento profissional seja equivalente e possibilite a manutenção de uma vida social saudável e de melhor qualidade, sua e de seus familiares.

Entender o significado dos papéis assumidos pelo indivíduo e sua importância no contexto social se torna fundamental. Para Moreno (1978), o papel é visto como a postura escolhida pelo indivíduo para lidar com certa situação. É o comportamento que ele assume na interação com os diversos atores que fazem parte de sua vida, seja no âmbito pessoal ou no profissional. 
Relativamente à família, é reconhecido que a estrutura familiar tradicional tem sofrido várias alterações ao longo dos últimos vinte anos, em razão do surgimento de novos elementos nos níveis social, político, econômico e cultural. Apesar disso, essa estrutura ainda é considerada essencial para o desenvolvimento e crescimento do indivíduo, de acordo com Koloustian (1978). É através dela que se constroem os valores e hábitos do indivíduo como forma de preparo para atuar no mundo externo. É ainda na convivência familiar que ele pode encontrar o seu porto seguro, onde os vínculos afetivos se consolidam com maior força.

Compreende-se que o equilíbrio seja o ponto central para minimizar ou impedir o efeito negativo do conflito, a partir do momento em que interfere na vida do indivíduo. Ou, segundo Follet, (1997, citado por SILVA E ROSSETTO, 2010, p. 43), ao reconhecer o conflito, "Em vez de condená-lo, [...] fazer com que trabalhasse a nosso favor".

Considera-se como fundamental que o indivíduo identifique e trabalhe da melhor forma possível os fatores que mais o afetam, enquanto seres individuais ou sociais, buscando o equilíbrio entre ambos os papéis para o alcance de seu bemestar.

Pretende-se no presente trabalho caracterizar o conflito família/trabalho existente em um grupo específico de mulheres gerentes, em uma instituição bancária, e as formas que elas encontram para alcançar o equilíbrio entre a vida pessoal e a vida profissional.

O desenvolvimento desse trabalho, longe de fornecer soluções mágicas para reduzir ou evitar o surgimento do conflito, teve como objetivo conhecer a realidade pessoal e profissional das participantes do estudo, descrever o conflito vivido e identificar as formas encontradas para lidar com ele. Essa motivação surgiu da inquietude e da observância dessas ocorrências ao longo da vida profissional da autora, tendo percebido seu impacto na vida de mulheres em cargos de chefia.

Através do referencial teórico será dado o devido embasamento, por meio de estudos já realizados sobre a inserção da mulher no mercado de trabalho, os diversos papéis que ela desempenha e o impacto sobre sua vida por mais essa atividade desenvolvida.

Em seguida, será apresentada a metodologia adotada para descrição das variáveis encontradas, que possibilitaram o entendimento do impacto que essas exercem sobre a vida das participantes do estudo. Posteriormente, ao serem 
analisados os dados colhidos, permitiu-se a discussão e conclusão do presente trabalho.

\subsection{Formulação do problema}

Para atender aos parâmetros de clareza e precisão, empirismo, delimitação e solução (GIL, 2002), o problema de pesquisa será: Como lidam com o conflito família/trabalho mulheres gerentes?

Como variáveis surgidas do problema de pesquisa, estas serão delimitadas ao "conflito família/trabalho" e ao "gênero".

A seguir, definem-se o objetivo geral e os específicos, vistos como fundamentais para caracterização da finalidade da pesquisa.

\subsection{Objetivo Geral}

No sentido de responder-se ao questionamento da pesquisa, definiu-se explicitamente, de forma resumida, o proposto pelo estudo e as ações necessárias para alcançá-lo. Sendo assim, o objetivo geral desse projeto é a descrição do conflito família/trabalho existente em um grupo de mulheres gerentes de uma empresa pública e as formas encontradas para administrá-lo.

\subsection{Objetivos Específicos}

Procurou-se traçar objetivos que possam levar à descrição do conflito família/trabalho como se apresenta, através do conhecimento da vivência dessas mulheres.

Relativamente aos objetivos específicos, quando do detalhamento do objetivo geral, esses foram destacados como segue: 
- conhecer a realidade pessoal e profissional do indivíduo;

- conhecer o significado e a importância da família e do trabalho para as participantes do estudo;

- descrever o conflito família/trabalho existente nesse grupo;

- entender o impacto que o conflito exerce sobre a vida profissional e pessoal da mulher em cargo de chefia; e

- identificar as formas encontradas para lidar com o conflito.

\subsection{Justificativa}

A escolha do tema da pesquisa partiu de uma inquietação constante e da observação direta da autora no decorrer de sua atividade profissional, percebendo a ocorrência de conflito entre a vida pessoal e profissional dos indivíduos de sua convivência, bem como por experiência própria. Entendeu-se que o conflito surge da falta de equilíbrio entre essas duas facetas da vida do indivíduo e que o sofrimento causado por ele exerce forte impacto na atividade laboral diária, motivando-se a conhecer e caracterizar as diferentes visões sobre o tema.

Para delimitação do tema buscou-se literatura pertinente. Dos artigos selecionados e correlatos ao assunto, percebeu-se uma lacuna quanto ao conflito família/trabalho relativamente ao gênero mulheres gerentes em instituição bancária, tendo em vista que no artigo de Silva e Rossetto (2010), um dos motivadores do presente estudo, a pesquisa foi direcionada para o gênero masculino, com gerentes de uma instituição bancária, com uma visão diferenciada, qual seja conhecer-se o impacto do conflito trabalho/família.

Reconheceu-se que o conflito "está vinculado ao tempo dedicado ao exercício de papéis no trabalho e na família, à incompatibilidade de interesses e às divergências de percepção e de visão entre os agentes envolvidos". E, acatando sugestão dos autores, escolheu-se investigar o conflito sob uma nova visão, ou seja, "considerar os vínculos entre o gênero, a personalidade, o contexto, o tipo de trabalho e o estágio na carreira" (p.41). 
Igualmente motivador para a elaboração da pesquisa, o artigo de Lindo et al (2007) chama a atenção para a influência que a especificidade do ramo de atuação pode exercer na geração do conflito e, consequentemente, interferir na relação família/trabalho e no encontro do equilíbrio entre a vida pessoal e a vida profissional para mulheres empreendedoras.

Além de buscar conhecer e descrever o conflito família/trabalho entendeu-se que esse assunto seja de extrema importância, uma vez que muito se vê, em ambientes de trabalho e na vida pessoal, a necessidade em se ajustarem os tempos direcionados a essas duas facetas da vida do indivíduo. Entende-se ainda que com o equilíbrio evitar-se-ia que uma impactasse negativamente na outra e que há escassez de artigos abordando o assunto.

$\mathrm{Na}$ busca dessa estabilidade, o conhecimento do conflito e o entendimento de sua existência exercendo forte impacto sobre a vida do indivíduo pode contribuir com o gestor de pessoas, provendo-Ihe dados adicionais para a formulação e elaboração de programas que visem o bem-estar e a melhor qualidade de vida de seus funcionários nesse padrão operacional e, em contrapartida, o aumento da produtividade funcional. 


\section{REFERENCIAL TEÓRICO}

Para entender o conflito família/trabalho surgido com a inclusão da mulher no mercado de trabalho, mais precisamente quanto à atividade gerencial desenvolvida em uma instituição financeira, e os diversos papéis que ela desempenha nessas duas facetas de sua vida, pesquisou-se literatura pertinente para melhor embasamento do presente trabalho.

\subsection{O Mercado de Trabalho: planejamento em curto prazo}

Entende-se o trabalho humano como a ação que transforma a realidade de forma premeditada, voluntária, sendo essa ação dirigida por finalidades conscientes em busca da sobrevivência. Dessa forma, ao mesmo tempo em que permite a transformação da natureza, enquanto tarefa social, o trabalho possibilita que o indivíduo desenvolva suas faculdades, "estabelecendo relações mutáveis, que por sua vez alteram sua maneira de perceber, de pensar e de sentir" (ARANHA; MARTINS, 1999, p.5).

Ainda de acordo com as autoras, entendendo-o como uma atividade de relação,

[...] o trabalho, além de desenvolver habilidades, permite que a convivência não só facilite a aprendizagem e o aperfeiçoamento dos instrumentos, mas também enriqueça a afetividade resultante do relacionamento humano: experimentando emoções de expectativa, desejo, prazer, medo, inveja, o homem aprende a conhecer a natureza, as pessoas e a si mesmo (p. 6).

Complementando seu pensamento, afirmam que "o trabalho é condição de transcendência e, portanto, é expressão da liberdade" (p. 6).

Como se vê na literatura, os indivíduos têm sido exigidos cada vez mais pelas organizações, no tocante à maior flexibilidade, disposição para o trabalho e agilidade, haja vista que a busca por resultados rápidos é considerada imprescindível para aumentar a produtividade e competitividade das instituições em um mercado cada vez mais dinâmico. 
Para Sennett (2008), em razão do tempo, no qual a vida profissional passa a ser flexível e superficial cedendo ao curto prazo, as relações familiares seguem no mesmo ritmo. Por isso, a manutenção do casamento e os relacionamentos se mostram uma difícil tarefa, em razão de tanto o homem quanto a mulher estarem nesse círculo vicioso do trabalho, erigindo uma barreira ao convívio entre eles.

A supervalorização e a colocação do trabalho em primeiro lugar levam o indivíduo a se dedicar cada vez mais ao trabalho, relegando a um segundo plano sua vida pessoal, para quando houver tempo. Esse fato, no atual mundo capitalista, tem custado ao indivíduo um grande esforço físico e mental para priorizar, cada vez mais, a produção de bens e serviços para a satisfação das necessidades humanas (GIDDENS, 1997).

\subsection{Os papéis na vida do indivíduo}

A carreira é apontada pelo indivíduo como eixo primordial de sua vida e passa a ditar os valores pessoais a serem seguidos, na busca constante de superação e, em razão dessa ambição, acaba por submeter-se a uma escravidão profissional (PAGÈS, 1987, citado por TOLEDO, 2006), sacrificando a vida pessoal para atingimento do sucesso profissional.

Handy (1995, citado por VASCONCELOS, 2001, p. 24), declarou que,

O problema começou quando transformamos o tempo em uma mercadoria, quando compramos o tempo das pessoas em nossas empresas em vez de comprar a produção. Quanto mais tempo você vende, nessas condições, mais dinheiro fará. Então, há uma troca inevitável entre o tempo e o dinheiro. As empresas, por sua vez, tornam-se exigentes. Querem menos tempo das pessoas que eles pagam por hora, porém mais das pessoas que pagam por ano, porque, no último caso, cada hora extra durante o ano é gratuita.

Relativamente à família, Koloustian (1978, p. 22) diz que "[...] é o lugar indispensável para a garantia da sobrevivência e proteção integral dos filhos e demais membros", quando é essa que "propicia os aportes afetivos e, sobretudo materiais, necessários ao desenvolvimento e bem-estar de seus componentes".

De acordo com Silva e Rossetto (2010), foi constatado que a família é o centro das relações na vida dos gerentes, surgindo dela uma "visão socioafetiva e 
também indicaram a importância no estabelecimento de padrões de referência culturais e sociais". Como base de tudo que engloba a vida dos gerentes, evidenciou-se em sua pesquisa que a família, tanto a de origem quanto a que construíram, possui um "caráter dinâmico", sendo "determinantes em seu desenvolvimento pessoal e profissional" (p. 46).

Para isso, entender o significado de papel que o indivíduo assume e sua importância no contexto social se torna fundamental. Para Moreno (1978), o papel é visto como a postura escolhida pelo indivíduo para lidar com certa situação. É o comportamento que ele assume na interação com os diversos atores que fazem parte de sua vida, seja no âmbito pessoal ou no profissional.

Gaiarsa (1984, contracapa), em sua reflexão sobre "nós diante dos outros, sobre os outros face a nós e, principalmente, sobre cada um de nós em confronto com o seu próprio eu", corrobora com o pensamento de que todos são atores no palco da vida.

Baseando-se na literatura, sociologicamente falando, os indivíduos assumem diferentes papéis sociais no desempenho de cada função específica, de acordo com determinadas regras, interesses e valores sociais, na busca de obterem objetivos comuns. A própria sociologia utiliza-se de seu papel social para demonstrar que toda a atividade individual é influenciada pela sociedade e segue seus padrões.

Pela definição de Moreno (1978), veem-se os papéis sociais interpretados pelo indivíduo como uma forma de atenderem às expectativas da sociedade quanto ao seu comportamento e atitude em cada papel particular. Por isso, entende-se que todos os indivíduos, em qualquer sociedade, são sujeitos de papéis que pertencem a um sistema, buscando sua participação e integração com ele.

Pode-se usar nesse momento, extraído de Bloom (2000), o "axioma" de Shakespeare, citando palavras do filósofo francês Montaigne (1533-92), quanto ao mundo ser um palco; nesse palco todos são atores, com uma hora de entrada e saída, no qual todos desempenham muitos papéis. No palco, os atores sabem exatamente suas falas e o que vai acontecer, mesmo que finja, quando bom ator, não saber. Na vida, entretanto, não se sabe o que vai acontecer, mas finge-se que se pode aguentar o sofrimento, que pode chegar a qualquer hora sem aviso.

Por esse motivo, na busca de equilibrarem-se os diversos papéis desenvolvidos pelo indivíduo, com vistas a minimizar ou impedir a ocorrência do conflito e seu efeito negativo, Follet (1997, citado por SILVA E ROSSETTO, 2010, p. 
43), nos leva a pensar que "Em vez de condená-lo [...]" poder-se-ia "fazer com que trabalhasse a nosso favor".

\subsubsection{O Papel da Mulher na Sociedade}

De acordo com Lindo et al (2007), a literatura sugere existirem variáveis como gênero, idade e estado civil sendo responsáveis pela relação entre o conflito família/trabalho e a satisfação na carreira. Por sua ótica, as mulheres têm a família como prioridade em sua vida, diferentemente do homem que tende a priorizar a carreira, o que faz com que a primeira sinta o efeito negativo dessa escolha sobre a satisfação profissional.

Citando Greenhaus e Singh (2004), as autoras afirmam que a vida profissional tanto pode acrescentar quanto atrapalhar a vida familiar, e, de igual forma, a vida pessoal exercer a mesma influência sobre a vida profissional, porém, possuindo um peso maior para as mulheres, "[...] pelo fato de ainda terem grandes responsabilidades domésticas, as mulheres precisam buscar estratégicas para amenizar os conflitos existentes entre estas duas importantes instâncias de suas vidas" (p.2).

Lindo et al (2007, p. 6) citam que, no tocante à mulher empreendedora, o fato de que "A mulher tem sido responsável pelos afazeres domésticos, a sociedade ainda apresenta pressões e expectativas quanto ao papel feminino de ligação com o lar". Acrescentam que "Este fato seria decorrente do papel social inerente à mulher de responsabilidade com a família", em razão das "tradições da sociedade e da persistência da ideia de que as mulheres têm responsabilidade primária e fundamental de cuidar da casa e da família", ao citarem Ljungreen \& Kolvereid (1996).

Para Quelhas (2010, p. 3), "Na História Oficial, mulheres, trabalhadores e negros não tiveram participação [...]" tendo em vista que "quase sempre viviam a margem do poder monopolizado por altas camadas da sociedade".

Em sua análise histórica dos direitos das mulheres, o autor afirma que, já no século XIX, ainda "eram explícitos os padrões e condutas que o poder definia como desejáveis no comportamento feminino - trabalho e submissão" (p. 4). Verifica-se que, independente do período na história, incluindo-se o do capitalismo na 
atualidade, foi entendido por ele que o preconceito ainda faz parte da história de vida da mulher trabalhadora.

Ainda no início do século passado foi identificado pelo autor "uma clara divisão sexual do trabalho nas fábricas: [...]" (p. 4). De onde se conclui que a ascendência da mulher a atividades desenvolvidas no mercado de trabalho, seja em cargos públicos ou privados, ou, ainda, como empreendedoras, que passam a compor a nova realidade feminina, são recentes e ainda requerem muita luta e transposição de desafios.

Para romper essas barreiras, fica patente a disposição das mulheres em conseguirem seu espaço na sociedade capitalista e buscarem igualdade e reconhecimento pelo seu trabalho além das fronteiras de seu lar. Com essa postura, a partir dos anos 70, a mulher tem conquistado um novo espaço no mercado de trabalho, não ficando restrita ao ambiente doméstico, obtendo maior participação na população economicamente ativa do país.

Elas abriram novas perspectivas, seja como funcionárias, seja como empreendedoras. Essa nova realidade para o gênero vem se ampliando e sendo percebida, tanto no Brasil quanto no mundo afora, uma vez que a sua presença deixou de ser marcada apenas por jovens solteiras e sem filhos. Desde os anos 80, esse perfil passa a ser composto, também, por mulheres mais velhas, casadas e com filhos (BRUSCHINI \& LOMBARDI, 2002).

As autoras, descrevendo a evolução da inclusão da mulher e sua importância no mercado de trabalho, percebem que o aumento de sua participação vai além da simples necessidade econômica e das oportunidades surgidas. Os movimentos feministas nos idos de 1970 provocaram transformações culturais e de valores quanto ao papel desempenhado pela mulher na sociedade, colocando-a cada vez mais em evidência.

Sua atuação passou da administração doméstica, pura e simples, para recair, também, em cenários públicos, aumentando sua participação no mercado de trabalho. Para permitir a ascensão no trabalho produtivo, percebe-se a constante e crescente presença feminina, também, em escolas e universidades, atingindo maior nível de instrução.

Esses fatores, dentre outros, para Bruschini \& Lombardi (2002) poderiam ser a explicação do crescimento da atividade feminina e das alterações constatadas nas estruturas familiares desde a década de 80. Entre essas alterações, a redução no 
número de filhos por mulher e, consequentemente, no número de membros por família, e maior número de famílias chefiadas por mulheres podem ser caracterizados como exemplos atuais.

As autoras afirmam que

Não pairam dúvidas, portanto, sobre o avanço das mulheres na aquisição de escolaridade, o que Ihes propicia maiores credenciais para seu ingresso e permanência no mercado de trabalho em ocupações que requerem estudo (p. 96).

Relativamente à escolaridade, Quelhas (2010) compartilha com Bruschini \& Lombardi (2002) o "reconhecimento dos altos índices de escolarização das mulheres". Chama a atenção que, além da escolaridade, "novos padrões demográficos e culturais (p. 7)" contribuem para a participação das mulheres em cargos de comando, inclusive ressaltando a "indiscutível competência profissional feminina" (p. 8).

Entretanto, ainda se percebe "a sexualização das ocupações", que pode ter origem no início do seu desenvolvimento escolar, causando "efeitos perversos sobre a inserção feminina posterior no mercado de trabalho" (BRUSCHINI \& LOMBARDI, 2002, p. 97).

Tendo assumido seu lugar na população econômica ativa, Quelhas (2010, p.9) afirma que à mulher não se pode mais negar a importância de sua participação no mercado de trabalho, o que ele chama de "deslocamento das fronteiras da desigualdade" e "um processo de reconstrução das imagens de gênero", discorrendo que,

Nesse imaginário em processo de reconstrução, o lugar das mulheres deixa de ser a esfera doméstica e privada, e pode ser também a esfera produtiva e pública; o seu 'destino' não é mais apenas aquele de ser mãe e esposa, mas pode também ser o de uma trabalhadora (p. 10).

Percebe-se que o exercício de atividades profissionais ainda leva as mulheres a travarem várias batalhas em um mercado de trabalho masculino, devendo comprovar sua competência, principalmente no exercício de cargos de liderança. Pode-se dizer que, além de a elas serem propiciadas menores oportunidades do que aos homens, ainda precisam mostrar seu comprometimento, potencial e capacitação diariamente, e, também, conciliar seus afazeres domésticos e cuidados com a família. 


\subsection{O Conflito Família/Trabalho}

$\mathrm{Na}$ busca para construir o presente referencial teórico, confirma-se que o conflito tem sido descrito e estudado ao longo dos tempos.

Em seus ensaios, que se mostra tão atual, Michel de Montaigne (1533-92) já questionava a perspectiva essencialista que atribui aos homens e às mulheres identidades fixas, discutindo, no ensaio "Da incoerência de nossas ações", a natureza fluida e paradoxal dos seres humanos. Sua afirmação é de que somos todos feitos de peças e pedaços juntados de maneira casual e diversa, e que cada peça funciona independentemente das demais; assim, existe grande diferença entre nós e nós mesmos no correr do tempo. De igual forma é a diferença entre nós e os outros.

Define-nos como extremamente contraditórios. Ao mesmo tempo castos e lascivos; respeitosos e insolentes; modestos e arrogantes; pródigos e avarentos, de acordo com as circunstâncias apresentadas. Assim, tais circunstâncias são as que determinarão o uso das diferentes máscaras, que mostramos e escondemos, de acordo com as nossas conveniências.

Identifica-se como conflitante qualquer situação onde esteja presente a oposição de algum interesse ou valor, seja em nível pessoal, interpessoal ou grupal, podendo surgir o conflito quando as pessoas, no afã de defender suas ideias e atitudes, contestam a posição do outro.

Essa visão vem corroborar com o entendido por Touzard (1981), quando descreve o aspecto afetivo do conflito ao afirmar que,

[...] uma relação antagônica a respeito de um mesmo objetivo ou pela busca interdependente de objetivos contraditórios, assim como pela natureza e quantidade de poder que possuem os atores, implica certas atitudes, estereótipos e representação dos ditos atores, uns a respeito dos outros ( $p$. $64)$.

A busca por conhecer a origem do conflito, principalmente organizacional, tem atravessado os tempos e sido objeto de estudo de muitos autores, tanto em livros quanto em artigos, publicações acadêmicas e em periódicos. Em Robbins (2002) encontra-se o conflito definido como sendo "[...] um processo que tem início quando uma das partes percebe que a outra parte afeta, ou pode afetar, negativamente, alguma coisa que a primeira considera importante" (p.373-374). Para ele, o processo 
conflituoso, desde a origem até suas consequências, afeta negativa ou positivamente o indivíduo no tocante ao seu desempenho.

São nesses termos que se relaciona o interpretado por Lindo et al (2007, p. 4) ao expressarem que, "quanto mais tempo o indivíduo se dedica ao trabalho, menos tempo terá para dedicar-se à família, [...] aumentando o conflito trabalho-família”. Pelo prisma conflito família-trabalho, de igual forma, "quanto mais tempo se dedicar à família, menos tempo terá para o trabalho", o que implica em aumentar o conflito família-trabalho.

Nessa visão, apoiada por Noor (2002), as autoras afirmam que o menor ou maior peso atribuído a qualquer uma dessas facetas da vida do indivíduo (família e trabalho) é motivo para impactar negativamente uma sobre a outra. No entanto, citando Renaud, Guérin e Caussignac (2002), constatam que as pesquisas revelam maior incidência do conflito a partir do trabalho, apesar de perceber que os mesmos autores apontam, ainda, que,

[...] de forma conflitante, as pessoas em geral tendem a diminuir mais as responsabilidades com a família do que com o trabalho, isto porque os empregados tendem a acreditar que sofrerão consequências negativas em maior intensidade, se negligenciarem mais a vida profissional do que a familiar (p. 4).

Apesar de o presente estudo visar à compreensão e entendimento do conflito família/trabalho afetando mulheres em cargos gerenciais, pode-se constatar em Silva e Rossetto (2010), que, mesmo tendo desenvolvido sua pesquisa com homens gerentes,

O conflito entre a prática gerencial e as relações em família está vinculado ao tempo dedicado ao exercício de papéis no trabalho e na família, à incompatibilidade de interesses e às divergências de percepção e de visão entre os agentes envolvidos (p. 49).

Para os autores, descrevendo o conflito família/trabalho, "a percepção dos gerentes é de que os conflitos nas relações em família os afetam emocionalmente e isso se refletiu em seu desempenho" ao desenvolverem suas atividades gerenciais, confirmando as identificações feitas nos trabalhos de Carlson et al (1995); Smyrnios et al (2003) e Wilson et al (2007), haja vista que os conflitos "levam a mudança de humor, a dificuldade de concentração, a preocupações e dificuldades na realização de atividades, uma vez que seus pensamentos se voltam para a situação que gerou o conflito no ambiente familiar" (p. 52). 
Dessa forma, os autores confirmam a "existência de uma bidirecionalidade dos conflitos entre a prática gerencial e as relações em família" (p. 52), citada por Marchese et al (2002).

Destaca-se, também, em sua pesquisa, que o conflito família/trabalho, quando observam os estudos feitos por Wilson, Polzer-Debruyne, Chen e Fernandes (2007) "envolvendo o equilíbrio na relação trabalho e vida pessoal", é responsável por provocar "atitudes negativas relacionadas ao trabalho, incluindo a redução da satisfação no trabalho, atrasos, absenteísmo, doenças, turnover e redução nos níveis de desempenho" (53). No entanto, essa falta de satisfação com a carreira escolhida não foi percebida pelos autores, quando da análise dos discursos dos gerentes entrevistados.

Ponderando-se que há uma crescente necessidade de gerir o conflito dentro das atuais organizações, o papel do gestor de pessoas destaca-se importante quando é levado em conta que o seu principal ativo, que tem sido considerado como um fator de diferenciação entre as empresas, é afetado pelo conflito.

A autora observou ao longo de sua carreira profissional que, a partir do momento em que esses conflitos passam a se constituir em um problema, é possível que tanto a lucratividade quanto a rentabilidade organizacional sejam afetadas, com a redução de produtividade. Por isso, entende-se como de fundamental importância para a saúde do indivíduo, e, consequentemente, da empresa, que o conflito seja efetivamente gerenciado pelo gestor de pessoas.

Em Rahim (2001), Taylor, Fayol e Weber, em suas teorias, preconizavam a eliminação de todas as fontes de conflito, a remoção de todos os elementos "irracionais", com a finalidade de produzir uma organização mais produtiva. Apesar de ter sido visto como um fator negativo ao longo dos tempos, na segunda metade do século $X X$, a existência de conflito, desde que administrado, pode ser entendido como positivo e indicar uma gestão efetiva e eficaz na organização.

Robbins (2002), em suas abordagens sobre o conceito de conflito, afirma que a gerência adequada do conflito torna-se motor de desenvolvimento social, gerando efeitos positivos a partir do momento em que se alcance uma solução integrada do problema, beneficiando as partes. Portanto, infere-se que a face "boa" ou "má" do conflito dependerá da eficácia com que esse seja gerido pela organização.

Relativamente ao projeto em constructo, a seguir descrevem-se a metodologia e técnicas de pesquisa identificadas na literatura e que, ao serem 
aplicadas, permitirão identificar, conhecer e entender a existência do conflito família/trabalho, assim como seu impacto na vida pessoal e profissional de mulheres em cargos de liderança e suas formas de lidar com ele. O que não exclui a aplicação de outra metodologia em trabalhos futuros. 


\section{MÉTODOS E TÉCNICAS DE PESQUISA}

Entendeu-se que, para serem aplicados métodos e técnicas de pesquisa adequadas à realização de um trabalho, é fundamental delinear com precisão o tema, as variáveis e objetivos que se pretendam alcançar.

Para Lüdke e André (1986) deve existir confronto entre os dados, as evidências e as informações coletadas sobre o assunto, bem como conhecimento teórico embasado por estudos anteriores já realizados a respeito do tema.

Nessa parte, para se responder as perguntas de Como? Com quê? Onde? Barreto e Honorato (1998) destacam que se devem detalhar de forma sequencial os métodos e as técnicas científicas que serão aplicadas no decorrer da pesquisa para atingir os objetivos propostos, considerando os critérios de maior rapidez, eficácia e confiabilidade das informações.

Considera-se que a metodologia deva ter estreito vínculo com o cenário que será pesquisado, apresentando características comuns a todos do grupo participantes, as quais devam ser devidamente detalhadas. Reveste-se de importância, ainda, a discursão dos fenômenos que ocorrem no universo escolhido para a pesquisa, utilizando-se um procedimento racional e ordenado, com instrumentos que possibilitem a reflexão e a experimentação no decorrer de toda a pesquisa.

\subsection{Cuidados éticos}

Em razão de normas internas a serem seguidas pela autora, no presente trabalho a caracterização da organização e das participantes de estudo será efetuada utilizando-se nomes fictícios. Quando houver a necessidade de citarem-se dados demográficos, socioeconômicos ou culturais para melhor esclarecimento da questão, será feito garantindo o sigilo, não expondo a participante. 


\subsection{Tipo e descrição geral da pesquisa}

A partir da identificação do problema de pesquisa "Como lidam com o conflito família/trabalho mulheres gerentes?" destacaram-se como variáveis a serem pesquisadas o "conflito família/trabalho" e o "gênero", as quais se buscaram conhecer e entender através da visão das participantes de estudo em uma pesquisa qualitativa.

Em razão de a pesquisa qualitativa e interpretativa tender a ser direcionada no decorrer de sua realização (NEVES, 1996), a escolha desse método no presente trabalho se justificou pela intenção em se obter dados descritivos sobre as participantes do estudo em interação com a pesquisadora, a partir do contato direto com a situação proposta (GODOY, 1995).

Godoy (1995, p. 62) destaca ainda a diversidade existente entre os trabalhos qualitativos e elenca algumas características que possibilitam identificar uma pesquisa desse tipo. As características destacadas são: i) o caráter descritivo; ii) enfoque indutivo; iii) o ambiente natural como fonte direta dos dados e o pesquisados como instrumento fundamental; iv) o significado que as pessoas dão às coisas e à sua vida como preocupação do pesquisador.

A pesquisa qualitativa permitiu maior abertura das questões que nortearam 0 trabalho, dos métodos e das técnicas utilizadas para a coleta e análise dos dados encontrados durante o processo. Contou-se também com uma abordagem fenomenológica, ao descrever-se diretamente a experiência, partindo-se de princípios tidos como verdadeiros, quando essa realidade pode ser explicada; ela é compreendida, interpretada e comunicada (GIL, 1999).

Imprimindo-se um caráter sequencial e lógico à pesquisa se pretendeu atingir os objetivos propostos, empregando-se uma metodologia que se propôs consistente com o panorama escolhido, com instrumentos, recursos e procedimentos condizentes para tratamento e análise dos dados colhidos.

Para o estudo de pesquisa quanto aos objetivos, buscou-se em Gil (2002) o método exploratório-descritivo para permitir uma abordagem de conhecimento dos fenômenos que foram aqui tratados, tendo em vista a necessidade de estimular as entrevistadas a discorrer livremente sobre o tema. 
Assim, a coleta dos dados partiu da emersão de aspectos subjetivos (dados primários), seja por motivações, não explicitas ou conscientes, de forma espontânea. Entendeu-se como apropriado esse método em razão da necessidade de descrever as percepções e entendimentos sobre a natureza geral do conflito família/trabalho no gênero, permitindo seu conhecimento pela pesquisadora.

\subsection{Caracterização da organização, setor ou área do objeto de estudo}

A organização escolhida foi o Banco Sudoeste, contando com um efetivo de 42 funcionários na agência selecionada.

A instituição, pessoa jurídica de direito privado, organizado na forma de banco múltiplo e integrante do Sistema Financeiro Nacional, com atendimento extensivo às diversas cidades e capitais do País, se faz presente, também, no exterior.

Cumprindo o seu papel econômico e social, em sua Missão estão contempladas as soluções em serviços e intermediação financeira, bem como os demais indivíduos de sua cadeia de relacionamento, quais sejam os clientes, acionistas e funcionários, mantendo, ainda, seu compromisso com o meio ambiente e com o desenvolvimento do País.

Em 2008, apesar da crise financeira global, o Banco Sudoeste manteve sua solidez, canalizando altos volumes de recursos internos e externos, registrando o maior lucro líquido entre os bancos nacionais.

É nesse cenário de solidez e compromisso com o desenvolvimento do país e da sociedade como um todo que foi desenvolvida a pesquisa.

\subsection{Participantes do estudo}

Para realização do trabalho optou-se por uma instituição financeira, mais precisamente uma agência do setor de varejo do Banco Sudoeste, em uma cidade do Distrito Federal, que promove o atendimento a pessoas físicas, incluindo-se alta renda, e jurídicas. 
Atendendo ao proposto, escolheu-se como participantes do estudo funcionárias do gênero feminino que desenvolvem seu trabalho nos diversos segmentos gerenciais existentes na agência, tendo como característica principal a liderança.

As participantes foram selecionadas intencional e propositalmente, evidenciando-se a amostra não-probabilística. A representação do nível gerencial permitiu configurar-se um direcionamento a esse padrão operacional, através de uma pesquisa qualitativa exploratório-descritiva.

A entrevista foi realizada com seis gerentes na faixa etária variando entre 30 e 51 anos, de acordo com o perfil e quantidade de funcionárias do gênero identificado na agência que exercem a função. A escolha da quantidade e da faixa etária visou abranger ocupantes da função gerencial nos vários níveis segmentados pela instituição, bem como de tempo de trabalho. Ocasionalmente, essa amostra poderia fazer emergir características outras como liderança, estado civil e maturidade como primordiais no desenvolvimento de suas funções.

Inferiu-se que a amplitude da faixa etária permitiria maior profundidade quanto ao conhecimento da visão de cada uma delas no tocante ao conflito família/trabalho.

Estão excluídos deste rol os funcionários lotados na Diretoria de Pessoas, para ter caracterizada, tão somente, a visão de quem sofre o impacto direto do conflito e não a visão organizacional.

\subsection{Instrumento(s) de pesquisa}

Tendo em vista que o presente trabalho define-se, metodologicamente falando, por uma abordagem de pesquisa qualitativa, a técnica que possibilitou a coleta de dados foi a entrevista, prescindindo-se de análise documental.

A entrevista com as participantes do grupo possibilitou os conhecimentos desejados, levando ao entendimento de como elas interpretam as experiências de conflito vividas.

Para evitar-se constrangimento entre as participantes, optou-se pela entrevista individual, com roteiro semiestruturado, aberto e flexível, possibilitando à entrevistadora, no decorrer da entrevista, tanto eliminar perguntas previamente 
definidas, quanto fornecer maiores esclarecimentos e subsídios para que a resposta fosse condizente com a pergunta, não dando margem a respostas incompletas ou que fugissem ao assunto, bem como esclarecendo possíveis dúvidas.

Durante sua aplicação viram-se reveladas as emoções, sentimentos e opiniões das entrevistadas, quando se pode comunicar, "através de um porta-voz, as representações de grupos determinados, em condições históricas, socioeconômicas e culturais específicas" (MINAYO, 1996, citado por ZANELLA, 2006, p. 120).

As informações foram extraídas a partir do cenário subjetivo das participantes do estudo, ao serem conhecidos seu modo de vida, tanto em família quanto no ambiente de trabalho, suas crenças, valores e visão de mundo, permitindo a compreensão do impacto que os acontecimentos exercem sobre elas.

Os conteúdos foram colhidos diretamente das participantes do estudo, quando apresentaram seus posicionamentos sobre o tema, esclarecendo as informações pertinentes ao objetivo proposto, motivo pelo qual foi semiestruturada e individual. Nesse momento, a coleta de dados ocorreu a partir da combinação da técnica de observação não participante e de entrevista semiestruturada (ALENCAR, 1999; QUEIROZ, 1988).

Foi elaborado um roteiro de entrevista com perguntas englobando as variáveis destacadas, quais sejam conflito família/trabalho e gênero. Esse roteiro foi dividido em três partes que contemplam: 1 - Conhecendo a realidade pessoal e profissional da participante de estudo; 2 - Descrevendo o conflito vivido; e 3 Identificando as formas encontradas para lidar com o conflito.

Em razão da característica ocupacional, esperava-se ver inseridas a liderança, estado civil e a maturidade como possíveis variáveis nesse contexto. Apesar de, inicialmente, não se pretender discorrer detalhadamente sobre elas no presente trabalho, entendeu-se que alguma delas poderia ser determinante para o pensamento captado.

As entrevistas individuais ocorreram no próprio local de trabalho das entrevistadas, quando essas foram gravadas e posteriormente transcritas literalmente, depois de obtido o consentimento de cada uma delas. Na descrição das entrevistas foram utilizados nomes fictícios, para garantia do anonimato das entrevistadas no fornecimento das informações. Pretendeu-se que a entrevista 
não ultrapassasse o tempo máximo de quarenta minutos, para que não se tornasse monótona e repetitiva, o que foi atingido a contento.

O procedimento de gravação e transcrição buscou manter a fidelidade e imparcialidade totais por parte da entrevistadora, no sentido de observar e apurar a opinião, pura e simplesmente, das entrevistadas. Foi realizado um total de seis entrevistas, não havendo nova coleta de dados, uma vez que essa não se mostrou realmente imperiosa para conclusão ou elucidação de dúvidas surgidas durante a análise, tendo essas sido respondidas entre as idas e vindas aos textos.

Depois de transcritas, as entrevistas foram submetidas à apreciação das participantes do grupo para confirmação da fidelidade na transcrição e posterior devolução para análise.

\subsection{Procedimentos de coleta e de análise de dados}

Para a coleta de dados, os procedimentos foram divididos em etapas a serem cumpridas para conhecimento, entendimento e descrição do conflito família/trabalho.

$\mathrm{Na}$ primeira etapa foram contatadas as participantes escolhidas para explicação do motivo, da finalidade do estudo e da necessidade em se gravar a entrevista, com a entrega de uma Carta de Apresentação garantindo o sigilo das informações e buscando sua concordância na participação do trabalho.

Com a anuência, foram marcadas as entrevistas previamente, sendo realizadas no mês de outubro, no próprio local de trabalho das participantes de estudo. O horário foi estabelecido por cada uma das gerentes, dentro de sua disponibilidade e obedecendo-se o horário anterior ao de atendimento ao público.

Anterior à realização da entrevista, avaliou-se a adequação do roteiro que orientou a entrevista, para que fossem contemplados todos os pontos fundamentais na identificação das variáveis necessárias para a análise e conclusão do trabalho, evitando-se o surgimento de pontos obscuros que viessem a dificultar essa análise.

$\mathrm{Na}$ segunda etapa, com a gravação da entrevista pretendeu-se conhecer o pensamento, sentimentos e emoções de cada uma delas em relação ao conflito família/trabalho que permeia suas atividades diárias. 
Recolhidos os dados, em conjunto com registro de observações da pesquisadora, no tocante a expressões corporais, faciais e outros sentimentos que afloraram durante o desenrolar da entrevista, na terceira etapa as entrevistas foram transcritas permitindo a fidelidade das informações prestadas.

Nesse momento, sintetizaram-se as informações em relação aos tópicos da pesquisa, procedendo-se a categorização com a definição dos propósitos de pesquisa; isolando-se os elementos e, posteriormente, agrupando-os (VERGARA 2005, p.18). A categorização foi pertinente, com grade aberta para que se definissem durante o andamento da pesquisa, e flexível para permitir alterações até obtenção do conjunto final.

Posteriormente à categorização, a autora sentiu a necessidade em obter uma perspectiva geral dessa, para que os elementos agrupados refletissem realmente 0 pensamento de cada uma das entrevistadas, enfocando os temas de forma abrangente. Essa necessidade surgiu do fato de o roteiro de entrevista contemplar perguntas correlatas em diferentes momentos, cujas respostas se encontravam em tópicos distintos. Para isso, elaboraram-se quadros temáticos, tendo o seu preenchimento possibilitado a revisão dos resultados e sua reestruturação de acordo com a literatura pertinente.

Para conhecer e entender a visão das participantes de estudo, a análise e interpretação de dados permitiu apresentar os resultados advindos da pesquisa em consonância com os objetivos propostos (RAUEN, 1999).

Seguindo a orientação de Triviños (1987), para a análise de conteúdo observaram-se os passos de: pré-análise (organização do material), descrição analítica dos dados (codificação, classificação, categorização), interpretação referencial (tratamento e reflexão).

Nessa fase da pesquisa, ao disporem-se os dados por categorias, foi possível responder à pergunta da pesquisa, dando a amplitude necessária às respostas, tendo-se como base outros trabalhos de conhecimento já realizados. Essa comparação teve o intuito de encontrar pontos em comum e pontos de discordância em um processo análogo, com interpretações individuais e globais.

Para atingimento do objetivo, analisou-se o conteúdo com base em Silva e Rossetto (2010), intencionando-se compreender e interpretar os dados coletados. Ao "delimitar os passos para compreender o fenômeno" surgiu deles as categorizações para análise, possibilitado pela "ida e volta entre pedaços de 
dados concretos e conceitos abstratos, entre o raciocínio indutivo e dedutivo, entre a descrição e a interpretação" (p.46).

Ao serem categorizados os dados entre visões semelhantes e destacadas aquelas que diferiram da maioria, procurou-se atender ao proposto no presente estudo quanto ao conhecimento, entendimento e descrição da existência do conflito família/trabalho, sua importância e impacto no cotidiano de mulheres em cargo de chefia, dentro do cenário pré-estabelecido, identificando as formas encontradas para administrá-lo. 


\section{RESULTADOS E disCUSSÃO}

\subsection{Conhecendo a realidade pessoal e profissional da participante do estudo}

A partir desse momento, buscou-se conhecer o histórico pessoal e profissional das participantes de estudo e sua realidade atual; quanto ao papel da família e do trabalho em suas vidas, para identificar (ou não) a existência de sentimentos conflituosos nos diversos papéis que desempenham.

As participantes vêm desenvolvendo suas atividades no banco entre 5 e 31 anos de serviço. Dentre elas, duas são casadas e têm dois e três filhos, respectivamente. Das quatro participantes solteiras, apenas uma tem um filho. Todas as gerentes possuem graduação, sendo: três em Administração, uma graduada, ainda, em Processamento de Dados; uma em Letras; uma História; e uma em Economia. Dentre as seis, cinco são pós-graduadas em Finanças, em Linguística, em Administração e em Docência do Ensino Superior.

\section{Quadro 1 - O Significado da Família, sua Base e Importância}

\begin{tabular}{ll}
\hline SIGNIFICADO DA FAMÍLIA & BASE E IMPORTÂNCIA DA FAMÍLIA \\
\hline - família é um porto seguro; & $\begin{array}{l}\text { - diálogo (como forma de apoio, leva ao entrosamento, } \\
\text { permite um acompanhamento da formação do caráter; é } \\
\text { uma forma de fornecer ajuda; através dele se chega ao } \\
\text { entendimento). }\end{array}$ \\
- família é um norte; & $\begin{array}{l}\text { - apoio (dos pais, marido, filhos; divisão de tarefas; para } \\
\text { solução de problemas profissionais, ajudar no cuidado } \\
\text { com os filhos e dar forças quando necessário; é um } \\
\text { alicerce para a formação do caráter, um "ombro amigo") }\end{array}$ \\
- é a base da vida de todos nós; & $\begin{array}{l}\text { - compartilhamento (envolvimento com o ambiente dos } \\
\text { filhos, atenção). }\end{array}$ \\
- família significa origem, refúgio. & $\begin{array}{l}\text { - convivência (harmonia, união, onde se compartilham } \\
\text { experiências, troca de ideias, auxiliando nas dificuldades, } \\
\text { partilhando as decisões e as dúvidas para um consenso, } \\
\text { estar presente constantemente). }\end{array}$
\end{tabular}




\subsubsection{Família simboliza apoio e formadora do caráter do indivíduo}

Com base na análise compreensiva e interpretativa, algumas vezes utilizando-se de indução e dedução, percebeu-se que a família, tanto a de origem quanto a constituída, possui importância e influência preponderante na vida das pessoas em geral. É ela quem fornece o alicerce para o desenvolvimento de cada um, sendo a mola propulsora em todas as instâncias da vida do indivíduo.

A família é vista como provedora de afeto e o berço da formação do indivíduo (seu caráter), quando garante a proteção e a sobrevivência ao fornecer os aportes fundamentais, emocional ou financeiro, para que ele se desenvolva plenamente e alcance a felicidade e o bem-estar necessários para a sua vida adulta. Inclusive para desenvolvimento das atividades profissionais, confirmando as palavras de Koloustian (1978).

Notou-se ainda que, apesar de terem o mesmo significado, na maioria dos discursos a família foi descrita de uma forma diferente, não tendo incidência de frases idênticas. Esse fato contribuiu para o conhecimento da diversidade de sentimentos que a família desperta nas participantes do estudo. Essa diversidade é retratada no Quadro 5 (p. 75).

No entanto, esse entendimento quanto à família de origem não é partilhado pelo grupo de maneira unânime, destacando-se o entendimento de ser ela apenas o "ninho", ou seja, um local para nascer, crescer e aprender. Não havendo elo entre essa e as demais fases da vida.

Dentre os temas que possibilitaram esse entendimento, destacam-se: Um porto seguro; Um norte; É o que faz com que a gente levante todo dia e venha trabalhar; Aprendendo com os filhos; O centro da vida; É primordial, essencial, principal; Alicerce; Família é o lugar onde você nasce, cresce, aprende e sai fora; É a coisa mais importante do mundo; É a base para a vida; Significa origem. É o meu refúgio; Família é união. 
Segundo a gerente GM2,

"Família eu acho que é a base para a vida de todos nós, né? Família é o apoio, é segurança, é companheirismo. Uma família unida é muito importante para o ser humano se sentir, se sentir seguro e conseguir, poder oferecer no futuro uma família para seus filhos também".

Caracterizando a falta de elo entre as diversas fases da vida do indivíduo, a GM5 assegura que,

"Família é o lugar onde você cria. É o ninho. Você nasceu, você cresce e bate asas e sai... E mantém o relacionamento, claro [...]. Mas fora do... Do... Do ambiente da família. Família eu falo, assim, pai, mãe, irmãos, assim, né?"

Diante do entendimento das participantes de estudo quanto à importância da família em suas vidas, buscou-se conhecer o que se destaca como fundamental na vida familiar, de que forma elas organizam suas vidas e quais as prioridades no dia a dia, no sentido de justificar-se essa importância.

Dentre as questões levantadas por cada uma delas, pode-se isolar um elemento comum que é o "diálogo" como apoio, apesar de apenas implícito em algumas frases. Verifica-se como primordial que haja diálogo entre os membros da família para haver entrosamento, auxílio, ou, ainda, "um ombro amigo" em um momento mais crítico.

Demonstram bem esse entendimento os temas a seguir: Diálogo, comprometimento; Esse apoio é muito importante; O apoio é fundamental; Um apoio; Uma mistura de tudo, diálogo, comprometimento com a família; É o diálogo, porque o diálogo leva ao entrosamento.

Um exemplo da importância do diálogo é o expressado pela GM1, quando diz que "O diálogo, né? Porque através do diálogo vem a ajuda... Então é isso que a minha família procura fazer uns com os outros. Diálogo e ajuda." (QUADRO 5, p. 75).

\subsubsection{A organização e a priorização são necessárias, mas nem sempre são conseguidas na forma em que se deseja}

Em relação à organização do cotidiano em família e suas prioridades, o Quadro 6 (p. 76) mostra que não existe uma rotina predeterminada, organizada, para a maioria delas. As coisas vão acontecendo e vão se organizando, seja em 
função de horários externos, seja através de hábitos constantes que se impõem. Somente uma das participantes informou possuir uma rotina diária, como forma de suporte e ajuda com o trabalho doméstico, além de garantir uma convivência mais próxima com a família.

Constata-se que a vida profissional possui, realmente, maior peso para as mulheres quanto às suas responsabilidades domésticas, quando há que se procurarem estratégias que amenizem essa influência sobre a vida familiar, acordando-se com Lindo et al (2007).

Sendo solteira a maioria das entrevistadas, foi passada a ideia de que, apesar de entenderem-na como necessária em suas vidas, não há tempo nem disposição para organizar o cotidiano, ou porque o dia seja "voltado para o trabalho", ou pelo fato de morar sozinha.

Os temas surgidos foram: Meu dia é voltado para o trabalho; Moro a muitos anos sozinha; Eu acordo, aí vou assistir um jornal; Eu não tenho ninguém que depende de mim; Já tem uma rotina que ela meio que já se predeterminou com a convivência; Todo domingo eu tenho o compromisso (prioridade) de ir almoçar com meus avós; Eu faço um esquema; Tem uma tabelinha que eles me ajudam; À noite a gente se reúne; A rotina vai se adequando aos horários externos; Nada assim muito fechado; Eu não organizo; Tentando fazer o que ainda dá tempo.

Para representar a ausência de uma organização consciente na área doméstica, o trecho a seguir a caracteriza:

"Não... Acredito que já é uma coisa predeterminada assim. Como só mora eu, minha mãe e minha irmã, então a gente já tem uma rotina que ela meio que já se predeterminou com a convivência [...]" (GM4).

A organização na rotina familiar se faz presente quando a GM3 afirma que:

"Eu organizo mais ou menos [...] Eu faço um esquema de todo dia um tem que fazer alguma coisa. Um leva a louça, estende a roupa. Tem uma tabelinha que eles me ajudam [...] Porque, senão, eu não dou conta. Não dou conta".

No tocante às prioridades, os filhos estão em destaque, haja vista o amor, a dedicação e o instinto maternal falarem mais alto entre as mães. A família como um todo, o diálogo, o estar junto também foi priorizado, tendo em vista o pouco tempo disponível para ela. Esse fato encontra embasamento em Lindo et al (2007, p. 11) nos dizeres de que "Mesmo aquelas mulheres que já têm filhos maiores expressam a importância de contarem com tempo para cuidarem de si e dos familiares". 
Para caracterizar o exposto quanto à prioridade em razão do tempo disponível para a família, os temas destacados do Quadro 6 (p. 76) representam o cotidiano dessas mulheres: Aproveitar bem esses períodos que estamos juntos; "Tão" ficando mais raros; À noite a gente se reúne; A prioridade seriam os filhos; Quando você se dispõe a estar com eles é entrar mesmo, de mergulhar; É chegar em casa, é conversar com meu filho.

Identificaram-se no discurso da GM2 e GM5, respectivamente, realidades distintas, apesar de a primeira referir-se basicamente à família e a segunda enfatizar mais o trabalho. Essa distinção pode ser resultante do fato de a segunda ser solteira e morar sozinha, o que poderia mudar caso houvesse família a cuidar.

"[...] Primeiro a prioridade seriam os filhos, a necessidade dele, de dar comida, e fazer o dever de casa [...] e, depois, as outras coisas. Jornal. Mesmo a gente querendo fica pra segundo tempo. Marido, a gente tem que ir intercalando entre filhos e atenção também... [...] Então, é essa regra. Primeiro eles, depois as outras coisas." (GM2).

Demonstrando uma realidade distinta:

"[...] O que eu priorizo? Não tem como priorizar. [...] O trabalho que eu faço aqui não tem o que priorizar. Se eu vier com alguma coisa priorizada na minha cabeça, eu vou chegar de tarde frustrada porque eu não fiz. Entendeu? [...] Ah, eu não tenho compromisso com filho, com de dar comida pra ninguém. Sou só eu, e... Eu não tenho que ficar preocupada. [...] É a vantagem de quem não tem filho,..." (GM5).

\subsubsection{A qualidade do tempo dedicado à família não está atrelado à quantidade que se tem; ora essa quantidade faz a diferença.}

Confirma-se nos discursos das participantes do estudo a necessidade de disporem de mais tempo para os cuidados que a família exige e um tempo para si mesmas, conforme identificado por Lindo et al (2007).

Apesar de a maioria entender como necessária a qualidade do tempo que se dedica à família em função da falta de quantidade, para a GM1 e GM5 o quesito quantidade também influencia, tendo em vista que no discurso de ambas a quantidade seria fator de peso para que se obtivesse qualidade (QUADRO 6, p.76).

Os temas a seguir retratam o pensamento das participantes: Qualidade, já que quantidade não é frequente; É tão bom quando você olha "pro" relógio ainda falta um dia para acabar o final de semana; Prezo mais a qualidade; Qualidade, sem dúvida; Eu acho que a quantidade também conta. 
Esse entendimento quanto à importância da qualidade do tempo vivenciado em família foi confirmado com o discurso da GM6, quando diz que é a "Qualidade, já que a quantidade não é frequente", o que também está presente na maioria dos discursos; sendo discordado, em parte, pelo discurso da GM1, como pode ser constatado na transcrição abaixo. De qualquer maneira, não se percebe grande divergência de opiniões.

"Eu acho que... Embora todo o mundo fale que é qualidade, eu acho que a quantidade também conta, porque não adianta eu ter só meia hora, [...]. Por mais que você aproveite, o tempo é pouco demais. $E$ tinha que ter quantidade sim, porque é através da quantidade que a gente vai fazer a qualidade, né? Praticamente." (GM1).

\subsubsection{No cotidiano, entre os múltiplos papéis desempenhados pelas mulheres todos encontram o seu lugar no devido tempo}

Mesmo estando presentes o cansaço, o sofrimento, o estresse e a necessidade de ajuda profissional, entre outros, os múltiplos papéis a que estão sujeitas vão encontrando o seu lugar no devido tempo. Em razão da cobrança que algumas delas se fazem, entendem que poderiam direcionar e resguardar o tempo de cada um, família e trabalho, aproveitando-o ao máximo quando em momento de lazer.

Diferentemente dos homens que priorizam a vida profissional, segundo indica a literatura especializada, as mulheres tendem a manter um equilíbrio maior entre esses dois papéis.

Entre as participantes do estudo, o trabalho é absolutamente necessário para a satisfação, para a dignidade e para a valorização enquanto seres humanos, percebendo a concordância com o pensamento de Aranha e Martins (1999, p. 6) quando essas autoras enfatizam que "o trabalho é condição de transcendência e, portanto, é expressão da liberdade", sem que seja preciso relegar a vida familiar e pessoal, apesar de entenderem que há ocorrências algumas vezes.

Apesar de realidades distintas e visões muito particulares para cada tópico proposto, a importância dada à família se faz mais uma vez presente, quando as participantes do estudo definiram a mãe e a mulher, as interferências sentidas e o apoio recebido pela família com relação ao trabalho e o que se faz primordial para seu bem-estar, constantes no Quadro 7 (p. 78). 
Entre as mães, a preocupação com os filhos é frequente, e a mulher é vista como um misto de todos os papéis vividos no cotidiano; ora o papel de mãe se sobressai, retratando o amor incondicional, ora a profissional fica em primeiro plano; ora a mulher é focada, ora a amiga, a colega.

Embasando esse entendimento, os temas destacados foram: Sou mãe, sou profissional, sou dona de casa. Só; Cuidado/Zelo; A mãe sempre se sobrepõe a tudo; Senso de proteção; Se dedicou, que amou mesmo seus filhos; Determinada, pacifista; Preocupada com o futuro; Desejável; Gosta das coisas certas; Trabalha; Assume compromisso; "Tá" sempre amiga; Voltada para melhorar sua performance; Sempre é primeiro mãe; Eu tenho também que priorizar meus filhos.

O papel da mãe se sobrepondo aos demais é confirmado pela GM3 que deseja ser lembrada como “... uma mãe que se dedicou, que amou mesmo seus filhos... Que buscou o melhor pra eles". No que é compartilhada pela mãe GM2, determinando que

"Sempre, sempre é primeiro mãe pra depois você pensar em seja qual for a outra coisa. [...] eu, como mãe, eu sempre dou prioridade aos meus filhos [...] você sempre pensa primeiro no lado materno para depois pensar nas outras coisas".

Quanto aos outros papéis vividos por essas mulheres, o discurso da GM5 mostra que a profissional "[...] gosta das coisas certas, gosta... Faz o que pode e o que não pode... Trabalha... O que ela tem que fazer ela faz; ela assume compromisso. Ela briga com quem não assume [...]".

\subsection{5 $O$ apoio familiar é a base para o bem-estar do indivíduo}

No quesito bem-estar, percebeu-se a "harmonia" como fator indispensável, mesmo que apenas implícito em alguns discursos. Também o individualismo se fez presente. Mas, de uma maneira geral, além da harmonia, a presença, 0 comprometimento, o saber que as pessoas estão bem e buscarem manter a paz entre todos são motivos para contribuir para o bem-estar delas (QUADRO 7, p. 78).

Por isso, quanto à família, pactua-se com o descrito por Silva e Rossetto (2010, p. 5) ao perceberem que ela "possui um "caráter dinâmico"' e que são "determinantes em seu desenvolvimento pessoal e profissional".

Dentre os temas localizados então: Só estar com eles. Só a presença mesmo; Estar mais presente na vida deles; Quando não existe conflito; Harmonia; União; Ter 
minhas coisas do jeito que eu gosto; Pensar no coletivo; Falta de comprometimento; Preocupada com o futuro.

Retratando esse panorama, em seu discurso, a GM2 confirma o entendimento de que harmonia é fundamental ao afirmar que,

“[...] Uma família que é desunida não traz benefícios pra ninguém. E quando a família tem harmonia, é entrosada, se entende... É isso que eu procuro muito passar pros meus filhos. Eles têm que ser unidos [...] que família é união... Que família é isso, pra gente e 'pro' resto da vida. Quando você tem harmonia, quando existe amor, é importante [...] É um suporte para você levar pra vida fora bem."

Confirmou-se ser essencial o apoio familiar, seja da família de origem, seja da família constituída. Percebe-se nas falas "Não tanto quanto a gente gostaria" e "parece que não entende" que, em muitas situações, a falta de apoio ou sua existência em menor escala do que se esperaria pode gerar conflito ou mesmo sentimentos de mágoa e ressentimento.

Os temas a seguir dão mostra desse cenário de apoio familiar: Sempre apoiaram; Ela (mãe) acolhe os netos; O marido também apoia; A gente divide; Ele (filho) entende bastante; Sempre teve (apoio); Sempre ajudou; Eles apoiam; Não tanto quanto a gente gostaria; Gostaria que o apoio fosse maior; Sempre me apoiaram; Eles me incentivam; Apoio é fundamental; Embora trabalhe no banco também (namorado), parece que não entende.

A afirmação abaixo retrata bem esse apoio:

"É minha mãe, minha irmã... Assim. Meus avós, né, tem que contar com eles [...] Sempre me apoiaram. [...] Eles me incentivam sim [...] se eu falar que vou jogar tudo 'pro' alto... Que não vou querer mais nada disso, que eu vou embora... Vou morar um ano na Europa, minha mãe diz 'pode ir, vai'." (GM4).

\subsubsection{O trabalho: sinônimo de dignidade}

Ao conhecer a trajetória profissional das participantes de estudo, sejam provenientes de salas de aula, da iniciativa privada ou pública e uma delas com dedicação única e exclusiva ao banco, perceberam-se, tanto na fala quanto em suas expressões, uma profunda identificação com o trabalho em si e a satisfação sentida pelo dever cumprido. 


\section{Quadro 2 - 0 Trabalho: Significado e Representação na Vida do Indivíduo}

\begin{tabular}{|c|c|}
\hline SIGNIFICADO DO TRABALHO & REPRESENTAÇÃO DO TRABALHO \\
\hline - trabalho é dignidade; & $\begin{array}{l}\text { - dignidade (saber que pode se sustentar, caminhar com } \\
\text { as próprias pernas, permite vencer desafios e dá sentido } \\
\text { à vida). }\end{array}$ \\
\hline - ele é fundamental; & $\begin{array}{l}\text { - utilidade (a pessoa se sente completa; é necessário } \\
\text { para desenvolver o caráter; importante para se "ligar" no } \\
\text { que acontece no dia a dia). }\end{array}$ \\
\hline - trabalho representa satisfação; & $\begin{array}{l}\text { - realização (sentir prazer ao desenvolver uma atividade } \\
\text { e atender às expectativas do cliente e da empresa; } \\
\text { representa a independência e promove a } \\
\text { responsabilidade; ele é o retrato de uma vida inteira). }\end{array}$ \\
\hline & $\begin{array}{l}\text { - valorização (sente que é valorizado, que é capaz de } \\
\text { desempenhar bem seu papel profissional; permite a } \\
\text { autoafirmação). }\end{array}$ \\
\hline
\end{tabular}

Da mesma forma que identificado por Silva e Rossetto (2010, p. 11), percebeu-se que a possibilidade de se tornarem "pessoas unidimensionais" se repete, independente do gênero: também as mulheres gerentes, em razão do cargo, são levadas a dedicar grande parte de seu dia às atividades profissionais, tendo em vista que o trabalho em si, as metas, as capacitações e as cobranças, sejam delas próprias ou não, têm levado a sobrar, cada dia mais, menos tempo para cuidarem de si e de suas famílias. Identificou-se exceção no discurso da GM2 (QUADRO 13, p. 92).

Também entre as gerentes, o paradoxo citado por Silva e Rossetto (2010, p. 11) quando "os padrões de controle associados a um elevado nível de produtividade fazem com que o gerente valorize cada vez mais a dimensão trabalho e dedique a maior parte do seu tempo a questões relacionadas à atividade profissional" está caracterizado no tocante à maior dedicação de tempo às atividades profissionais, com pouco tempo para a família. Entretanto foi notado que a valorização à carreira não é maior do que valorização à família.

O trabalho é descrito por elas como algo que lhes é prazeroso, responsável por dar sentido à vida de qualquer pessoa, conforme o expressado no Quadro 8 ( $p$. 80). É visto como a ferramenta que promove a autoafirmação do ser humano, possibilitando alcançar sua independência e responsabilidade. Permite, ainda, que surja a satisfação do dever cumprido e o sentido de utilidade que ele promove, 
sendo fundamental para a dignidade humana. $O$ trabalho faz brotar um sentimento de que se é capaz e que é possível vencerem-se os obstáculos. Ou seja, o trabalho é "uma vida inteira" (GM5).

Dentre as palavras e frases que corroboram com essa afirmação, distinguemse: Ele é fundamental; É o trabalho que dignifica o homem; Não me vejo ociosa; Necessário para o caráter, desenvolvimento; Representa boa parte da minha vida; Satisfação; Sentir útil; Não me imagino sem trabalhar; Bastante importante; Dignidade; Trabalho é importante; Capaz de vencer desafios; Caminhar com as próprias pernas; Se sentir completa; Valorizado; Uma vida inteira; Eu gosto do que eu faço; Já fiz tanta coisa nesse banco.

Representando esse sentimento unânime, o discurso da participante GM2 consegue espelhar esse sentimento de dignidade que o trabalho incute nas pessoas quando diz que,

"[...] Eu acho que o trabalho em si, não só para mim, mas para todo o mundo é dignidade, né? Uma pessoa que não trabalha [...] eu acho que se ela não trabalhasse ela não se sentiria bem, [...]. Trabalho é importante pra você se sentir... Sentir bem, sentir que você é capaz de... De... De vencer desafios, de saber que você pode caminhar com suas próprias pernas, [...] eu acho que a pessoa que não trabalha não deve se sentir completa, porque o trabalho faz parte da vida do ser humano também, pra ele saber também que ele tem como se sustentar".

\subsubsection{As pressões diárias causam o sofrimento e o estresse}

As participantes, apesar de se identificarem com seu trabalho, gostarem do que fazem e do contato com o público, se ressentem do sofrimento que lhes é causado pelas pressões diárias sofridas e pelo assédio moral, no sentido de atingirem metas, muitas vezes, inatingíveis, ou que ferem o sentimento de ética pessoal, conforme discursos contemplados no Quadro 8 (p. 80).

Diante dessa constatação, "fica evidente que na prática gerencial a incidência de conflitos está associada a fatores individuais, grupais e organizacionais" (SILVA E ROSSETTO, 2010, p. 51). Há o entendimento de que metas são importantes e necessárias na vida de um ser humano, tanto pessoal quanto profissionalmente, mas que sejam factíveis (QUADRO 10, p. 85).

Contrariamente, há percepção por parte da GM5 de que ela simplesmente retribui o que o banco a paga para fazer, ou seja, trabalhar. Em seu discurso não se revela qualquer tipo de ressentimento ou sofrimento, mas sim comprometimento com 
o seu trabalho, independente do quanto desgastante ou estressante ele seja (QUADRO 14, p. 94).

Essa constatação pode ser entendida como uma contradição ao afirmado por Silva e Rossetto (2010, p. 53) quanto às "atitudes negativas relacionadas ao trabalho" na ausência de um equilíbrio envolvendo ambas as dimensões da vida do indivíduo. Em contrapartida, corrobora com a conclusão dos autores de que "a redução da satisfação não foi evidenciada" (p. 54), quando as gerentes demonstraram satisfação no trabalho realizado.

Os temas a seguir configuram essa realidade: Muito exigente em termos de metas; Tentar convencer (o cliente); O banco te exige posturas distintas; Empurrar produto; Não tenho muito esse trejeito de enrolar; Acanhada de me aproximar do cliente de forma que não acho adequada; Ser verdadeira; Isso não me faz bem; Apagando incêndio; Muitas metas; Metas inatingíveis; Acúmulo de serviço; E ser antiético (ao utilizar-se de artifícios para venda de produtos); Fazer coisas além da sua alçada; Só suprir vagas; Estou desestimulada; Pressão da meta versus assédio moral; Metas tem que ter; Como ela lhe é imposta; Causa depressão, um desânimo; Um desespero; Tudo que eu podia dar aqui já foi sugado; "Tá" meio que tirando o sono da gente.

A realidade descrita pode ser vista através do discurso que se segue:

\begin{abstract}
"Então, tenho bastante facilidade de trabalhar com pessoas [...] O que mata trabalhar em agência é a questão da pressão da meta versus a... Ao assédio moral... Eu acho. Porque metas tem que ter. Se você tem metas na vida, por que não no trabalho? Mas eu acho que como ela lhe é imposta... Como lhe é cobrado, que eu acho que é o que... O que a gente sente mais assim... É o que às vezes causa uma depressão, um desânimo, um... Sabe? Um desespero. Acho que é a forma como lhe é cobrada." (GM4).
\end{abstract}

\title{
4.1.8 A capacitação é essencial para o crescimento profissional
}

Vê-se nos discursos a visão de Quelhas (2010) quando, em razão das mudanças que vem ocorrendo tanto na instituição quanto no mercado de trabalho mundial, as exigências profissionais ditam a necessidade de se atualizarem de acordo com o novo modelo de competência que lhes é imposto. Isso as leva a buscar na qualificação a possibilidade de crescimento e desenvolvimento profissional (QUADRO 9, p. 83). 
Silva e Rossetto (2010, p. 51) afirmam que "A necessidade de qualificação profissional é um pré-requisito para a atuação de gerentes nas organizações em função do aumento da complexidade do contexto da prática gerencial".

Também no presente estudo constatou-se a importância dada à capacitação, quando se sentem preparadas para o cargo que ocupam e que correspondem ao perfil exigido pela instituição. Ou que estão muito além desse perfil em razão do conhecimento e formação acadêmica, possuindo potencial para crescimento dentro do banco. Ora percebeu-se dúvida nessa correspondência. Essa dúvida não é decorrente da falta de capacitação, mas sim do fato de que a dedicação exclusiva ao trabalho não está contemplada como prioridade na vida da participante do estudo, o que vem confirmar o identificado por Lindo et al (2007), referindo-se à visão de Noor (2002) quanto ao impacto negativo de uma sobre a outra. Outro ponto levantado é de que o banco não procura adequar o funcionário ao que ele tem de capacitação e possa satisfazê-lo, buscando tão somente preencher as vagas que vão surgindo.

Mesmo reconhecendo ser fundamental a qualificação profissional, as participantes do estudo enfatizam que, muitas vezes, não buscam novas qualificações por motivo de cansaço, ou pela não liberação por parte do banco para certa capacitação específica, quando há a necessidade de ser feita fora da instituição no horário de trabalho, apesar de o banco impor metas de cursos e das exigências quanto a cumpri-las. Nesse ponto, há entendimento de que a forma de pontuar do banco é meio complicada, mas há reconhecimento de que é difícil encontrar-se um padrão e o aplicar a todas as pessoas, de acordo com o descrito no Quadro 9 (p. 83).

Pelos discursos na tabela citada pode-se inferir que, apesar de disponibilizarem, os cursos que fazem parte da grade do banco não são suficientes para o crescimento profissional, ou que a aplicação maciça de cursos pode não atender ou ser dispensável para alguma função específica.

É vista como a base para o crescimento do indivíduo e da empresa e que, não raras vezes, há que se estudar em casa no horário de lazer. Notou-se, inclusive, que foi com orgulho e satisfação que a GM3 confidenciou já possuir cinco certificações. Também foi com orgulho que a GM5, pensativa, afirmou ter "31 anos de escrava". Esses discursos fazem parte dos Quadros 9 e 8 (p. 83 e p. 80), respectivamente. Entretanto, a falta de tempo para novas realizações quanto à capacitação é motivo de frustração para uma ou outra participante. 
Levantou-se, também, a necessidade de um trabalho psicológico com 0 funcionário aliado à preparação física e de conhecimentos para a execução do trabalho que é realizado. Essa necessidade é decorrente da diversidade de pessoas que são atendidas e assessoradas financeiramente, o que pode, muitas vezes, implicar em ajudar o cliente ouvindo seus desabafos pessoais, ou, ainda, aconselhando-o em assuntos não financeiros.

A gerente GM4 informou, inclusive, sua percepção de que as pessoas ultimamente estão mais preocupadas com o seu dinheiro do que com a saúde, o que se infere demandar certo tato do funcionário durante o atendimento (QUADRO 9, p. 83).

A constatação desses sentimentos, quando descrevem o perfil exigido, a profissional e a importância da capacitação, pode ser feita através dos temas: Eu acho que cumpro; Apesar do sufoco; Precisava melhorar; Não tem incentivo; Eles disponibilizam, mas não liberam; Saber negociar; Atitude, Responsabilidade; Capacidade de iniciativa; Assiduidade; Comprometimento; Conhecimento dos produtos e serviços da área de atuação; Correspondo de forma satisfatória; Atender a expectativa do cliente; Bons feedbacks; Não é 100\% em tudo; Me considero preparada; Busco melhora constante; Aberta ao diálogo; Sempre aprender mais; Já tenho cinco certificações; É uma coisa que eu busco muito; Nunca é demais; Perfil elevado para o cargo; Queima de talentos; Tenho vários cursos nessa área; Tenho um dom; Facilidade de trabalhar com pessoas; Isso aqui não é uma preparação só física; Ela também tem que ser bem trabalhada psicologicamente; Eles (clientes) estão muito mais preocupados com o dinheiro.

O discurso da GM3 apresenta essa necessidade de capacitação para crescimento profissional e a falta de tempo ou o cansaço que a impedem de, muitas vezes, realizá-la.

"Qualificação acho que é importantíssimo... É uma coisa que eu busco muito. Que eu não me qualifico mais em função do cansaço. Às vezes chego 'em' casa, ainda tem que estudar. Pra você ter uma ideia, eu já tenho cinco certificações [...] 'Tou' buscando mais [...] Que o profissional, se ele não se qualificar, ele vai ficando pra trás."

O que pode ser complementado pela gerente que diz

"[...] Às vezes a gente quer fazer até alguma coisa fora do banco e também não tem tempo, não tem incentivo [...] Quer dizer, alguns cursos têm aqui... Mas a gente não é liberado pra fazer [...] Eles disponibilizam, mas não liberam [...] Para o meu trabalho aqui, eu acho que sim (é suficiente a 
capacitação atual), mas para eu pensar em crescimento, em outras coisas, eu acho que eu teria que procurar fora do banco." (GM1)

\subsubsection{O diálogo se transforma na ponte para a integração social em qualquer ambiente, quando interferências podem comprometer o bom relacionamento}

Durante a coleta de dados, sentiu-se a necessidade de conhecer como é o convívio dentro das equipes e os fatores percebidos que mais interferem na rotina profissional quando do desenvolvimento do trabalho, relacionados nos Quadros 8, 9 e 10 (p. 80-85).

Nesse ponto, o diálogo, o apoio e a convivência, identificados por Silva e Rossetto (2010, p. 5), como "bases das relações em família" e que "auxiliaram os gerentes a evitar o surgimento de conflitos", também se mostraram presentes nesse estudo entre as mulheres. Acrescenta-se que, segundo elas, também essas variáveis são fundamentais nas relações profissionais, depreendido do Quadro 9 (p. 83).

Entendeu-se como curioso que, em nenhum momento durante a entrevista, 0 fato de serem mulheres em cargo de chefia tenha sido levantado por elas. Possivelmente, esse se justifique por entenderem estar presente o sentimento de equidade de gênero dentro da equipe, não havendo discriminação por serem mulheres. Nem que se ponha em causa a capacidade e o respeito devido na realização de suas tarefas. No entanto, não se pode afirmar que esses sejam os motivos, tendo em vista que não se buscou conhecer sobre discriminação de gênero no local de trabalho.

Dentro do clima organizacional, identificou-se a existência de coesão, de apoio, respeito, confiança e do diálogo ditando a postura na maioria dos respectivos grupos. É certo que para duas participantes do estudo essa realidade não foi descrita pela mesma ótica, haja vista perceberem um perfil mais distante e mais difícil para a convivência entre os colegas de trabalho (QUADRO 9, p. 83).

Entretanto, o diálogo se mantém como a palavra-chave para definir a convivência entre colegas de trabalho, considerando-se a "existência de um relacionamento pautado pelo compartilhamento de informações", conforme o indicado por Silva e Rossetto (2010, p. 7). 
Os temas levantados que confirmam esse entendimento foram: A convivência com a equipe de trabalho é muito boa; A gente sempre chama o colega e conversa; Aqui a gente tem bastante confiança; Ninguém pensa só em si; Há comprometimento; Diálogo como ponto de equilíbrio; Aqui o grupo é coeso; As pessoas são abertas ao diálogo; Eu sinto que a coisa flui bem; Depende do colega; Eu acho as pessoas mais distantes; A gente se respeita; Compartilha o que tem para fazer; Relacionamento bem profissional.

Para mostrar esse cenário de coesão, o discurso abaixo é característico:

"Prezo pela convivência com os meus colegas de trabalho e considero alguns mais próximos como amigos. Trabalho com uma excelente e unida equipe e há compartilhamento de ideias, pensamentos, emoções. Há comprometimento e colaboração entre os membros. Raramente, quando há divergências de objetivos e opiniões, sempre encontramos no diálogo o ponto de equilíbrio." (GM6).

Em contrapartida, a GM1 sinaliza que,

"Aqui... Em relação à amizade aqui, eu acho que o povo é mais distante. Em outra agência que eu trabalhei, a gente era unido, tanto dentro como fora do banco [...] Eu não sei se é porque aqui seja mais pesado, de repente. Acho que não... Acho que é o perfil das pessoas mesmo [...] A gente se respeita, a gente conversa mais sobre o trabalho, compartilha o que tem pra fazer, o que foi feito. Há ajuda aqui no nosso setor, mas o nosso relacionamento, realmente, é bem profissional."

Quanto às possíveis interferências na realização do trabalho diário, percebese no Quadro 10 (p. 85) que as opiniões não convergem para um ponto específico. Tendo em vista não haver rotina - apesar de alguma discordância nesse sentido não é factível elaborar e seguir um planejamento diário, e, quando elaborado, há a dificuldade na organização e cumprimento do planejado (QUADRO 8, p. 80). Outros fatores também se fazem presentes nessa interferência.

Como poderá ser visto mais adiante em tópico específico, nesse momento não foi citada qualquer interferência familiar que comprometa o desenvolvimento do trabalho.

Contribuindo com tal entendimento, os temas levantados foram: As pessoas não fazerem as suas partes; Aqui não tem rotina; Resolver o que aparece; Excesso de informações e cobrança; Excesso de demanda diária; Sempre uma surpresa; Excesso de cobrança de metas e resultados; Adoto uma certa rotina sim; Lido com o inesperado a todo momento; Ser perfeccionista e metódica; Nem sempre as coisas saem do jeito que você quer; As demandas podem acontecer de qualquer tipo; $\mathrm{O}$ 
meu trabalho é rotineiro (quanto ao horário); Demanda diferente no dia a dia; Ele já é uma rotina natural; Uma coisa totalmente rotineira; A quantidade de pessoas; Não "tá" com o setor completo; A demanda é grande; Tem muito telefone que interfere; Até tento fazer uma rotina, mas nem sempre você consegue seguir isso; O próprio trabalho, o superior, as metas do banco, as regras e normativos; De casa eu procuro não trazer não; Não tem como priorizar; Se priorizar, eu vou chegar de tarde frustrada porque eu não fiz; Elas (as coisas) vão acontecendo e vou resolvendo.

Mostrando essa realidade quanto ao descrito acima, as verbalizações que confirmam os temas quanto à interferência na realização do trabalho são:

"[...] Eu vou falar do momento que eu 'tou' vivenciando. O que 'tá' mais interferindo é assim a quantidade de pessoas [...] Como o nosso setor era pra ter uma quantidade maior, e agora em função da estratégia [...] a gente não tá com o setor completo [...] Às vezes você tem que sair do seu foco e atender o colega [...] Tem muito telefone que interfere. Acho que telefone interfere muito. Se eles conseguissem equalizar essa situação do telefone melhoraria muito a qualidade tanto do atendimento quanto do serviço em si." (GM3).

Complementando esse pensamento, em relação à rotina diária, a GM2 afirma que

“Eu não consigo... Por mais que você tente. Você chega... Às vezes você
chega 'na' rua e pensa: vou fazer isso, aquilo, aquilo. Mas aí você acaba
chegando 'no' ambiente de trabalho e as coisas vão passando à frente e
acaba que a rotina nunca... Nunca acontece exatamente como ela deveria
acontecer. Sempre uma surpresa... A gente 'tá' apagando incêndio sempre."

\subsubsection{Ser reconhecida e aceita pode ser uma questão de foro íntimo}

Com relação ao reconhecimento e aceitação, independente do papel desempenhado, no Quadro 10 (p. 85) verifica-se que não houve citação por parte da totalidade das participantes do estudo quanto à necessidade de estarem vinculados ao fator financeiro, sentindo-se que esses mantêm estreita ligação com a afetividade, corroborando com o estudo de Lindo et al (2007).

Igualmente à percepção de Silva e Rossetto (2010), a convivência harmônica no ambiente de trabalho se faz distinguida pelas participantes de estudo quando é reputado de grande importância o respeito, o reconhecimento ao trabalho realizado, a troca de experiências e aprendizagem através do compartilhamento de ideias e conhecimentos (QUADRO 9, p. 83). 
Confirmando o discurso de Quelhas (2010), ainda se faz notar que as mulheres estão em constante busca por seu espaço na sociedade e que o reconhecimento faz parte de suas aspirações no desenvolvimento de seu trabalho fora do lar.

Pelo entendimento de que caminham juntos, para que se caracterizem 0 reconhecimento e a aceitação é necessário que sejam vistas e aceitas no grupo, tendo suas ideias e opiniões partilhadas pelos colegas; haja valorização e respeito pelo seu trabalho e pelas suas ideias, uma vez que a diversidade existe em qualquer ambiente, devendo-se respeitar a opinião alheia. Reclamam que, independente do que já fizeram ou estão fazendo, o reconhecimento deve acontecer, o que não ocorre com frequência, e não somente passar para outro trabalho ou meta sem que seja percebido o esforço despendido na tarefa anterior, ou no cumprimento da meta.

Nos discursos do Quadro 10 (p. 85) distingue-se, ainda, que o fato de outra pessoa reconhecer o seu trabalho não é primordial. Que o reconhecimento e a aceitação vêm de dentro das pessoas, sendo mais implícito do que explícito. Muitas vezes eles surgem da felicidade em se realizar alguma atividade, e, quando existem aceitação e conhecimento próprios, esse é transmitido às outras pessoas e elas acabam por reconhecer e aceitar o que foi realizado. Portanto, é algo que "brilha" de dentro para fora.

Estar com a consciência tranquila quanto ao trabalho realizado, o tendo feito "da melhor forma que foi possível" (GM5), também foi apontado como reconhecimento e aceitação, sem que haja dependência de outras pessoas para que eles existam, também caracterizado no Quadro 10 (p. 85).

Sendo assim, os temas que suscitaram essa discussão foram: Reconhecimento é mais próprio do que do outro; Mais implícito do que explícito; Isso vem de dentro pra fora e as pessoas enxergam isso; As duas coisas juntas; Reconhecimento é eu "tar" com a minha consciência tranquila do serviço cumprido; Caminham juntas; É você ser visto, ser aceito; Às vezes nem é visto o que a gente fez; Só pensa no próximo (trabalho); Independente do que tem pra fazer, o que a gente tá fazendo ou já fez tem que ser reconhecido; É que as pessoas percebam o esforço, a dedicação o empenho que você tem no que você faz; É meio que um sinônimo, é você ser aceito no seu grupo; As suas opiniões, mesmo que divergentes, elas sejam aceitas pelos outros; É ser valorizada e respeitada no que se faz; Você consegue vencer aquele obstáculo que lhe foi proposto e lhe agradece; 
Não é reconhecimento financeiro. Nada de troca financeira; $O$ ser humano não tem como um ser igualzinho ao outro; Sentir que sou importante pras pessoas; A qualidade do que eu faço.

O discurso a seguir caracteriza essa necessidade de reconhecimento;

"[...] Bem, acho que caminham juntas, né? Praticamente a mesma coisa... É você ser visto, ser aceito [...] Com suas qualidades e falhas... Com seus pensamentos, suas ideias [...] Muitas vezes falta a gente ser reconhecida. A gente trabalha tanto, tanto. A gente mal acaba um trabalho ou uma meta e vem outra; Às vezes nem é visto o que a gente fez... Tudo que foi feito, porque só pensa no próximo, em fazer mais e mais. [...] Então, eu acho que, independente do que tem pra fazer, o que a gente tá fazendo ou já fez tem que ser reconhecido." (GM1)

\subsection{Descrevendo o conflito vivido}

Para entender o conflito que perpassa 0 dia-a-dia das gerentes, e se realmente ele existe em suas vidas, é fundamental conhecer as percepção quanto ao significado do conflito e as diversas formas que ele assume no cotidiano. Os Quadros 11 a 13 (p. 88-92) descrevem os discursos que possibilitam esse entendimento, condensados no Quadro 3 a seguir.

\section{Quadro 3 - $O$ Conflito na Vida Profissional e nas Relações Familiares}

\begin{tabular}{ll}
\hline \multicolumn{1}{c}{ CATEGORIAS } & ORIGEM \\
\hline $\begin{array}{l}\text { Fatores geradores de conflito no } \\
\text { âmbito profissional; }\end{array}$ & $\begin{array}{l}\text { Diversidade. Divergência de interesses, ideias e opiniões. } \\
\text { Aumento da complexidade do trabalho. Individualismo. } \\
\text { Cobrança excessiva. Não aceitação do outro. Não } \\
\text { conseguir realizar o que planejou. Intolerância. } \\
\text { Incompreensão. Metas inatingíveis. Assédio Moral. }\end{array}$ \\
$\begin{array}{ll}\text { Fatores geradores de conflito na } \\
\text { vida pessoal; }\end{array}$ & $\begin{array}{l}\text { Cobrança dos familiares (mãe, marido, filhos) e de si } \\
\text { própria. Falta de apoio e de tempo. Recursos financeiros. } \\
\text { Exigência do trabalho. O peso do trabalho. Dúvida quanto } \\
\text { à carreira. Preocupação com o futuro. Tentar conciliar } \\
\text { trabalho e casa. Ausência de apoio em razão da distância. } \\
\text { Dependência entre os membros da família. }\end{array}$
\end{tabular}

Atitudes que podem minimizar ou evitar o conflito entre a vida pessoal e a profissional
Diálogo. Disponibilidade de tempo para prática de exercícios físicos. Tempo para lazer. Compreensão por parte da família. Maior apoio. Buscar o equilíbrio entre os papéis desempenhados. Divisão de tarefas domésticas. Determinar prioridades. Aceitação da diversidade. Maleabilidade com relação a si e aos outros. União. 


\subsubsection{Entre os motivos do conflito, a diversidade existente na sociedade pode fazê-lo emergir a qualquer momento}

Apesar de ter-se confirmada, em alguns momentos, a relação conflituosa entre vida pessoal e vida profissional, o conflito não ditou o tom do discurso da maioria das participantes do estudo.

O conflito está caracterizado para uma parcela delas no sentido trabalho/família e dentro do próprio trabalho, mas não que o gênero, idade e estado civil "moldam a relação entre a satisfação na carreira e o conflito entre a família e trabalho", conforme afirmado por Lindo et al (2007, p. 4), mesmo que as mulheres priorizem suas famílias. Salvo uma participante mostrar insatisfação independente de conflito externo (GM4, QUADRO 7, p. 78), percebeu-se grande satisfação com o trabalho desenvolvido independente da presença do conflito família/trabalho.

A descrição do conflito e de sua origem foi feita pelas participantes do grupo como sendo algo inerente ao mundo e existente nas mais diversas situações e ambientes, "em virtude da divergência de percepções, visões e interesses na relação entre grupos" (SILVA E ROSSETTO, 2010, p. 8).

O não cumprimento de uma atividade, por falta de tempo ou impedimento por alguma norma; a não realização de um desejo, uma vontade, também são fatores geradores de conflito. Ainda pela falta de consciência do indivíduo quanto a si próprio e pelo individualismo exacerbado. A intolerância e o fato de as pessoas pensarem somente em si, pode se tornar, também, um obstáculo para que se instale a boa convivência (QUADRO 11, p. 88).

Dentre os temas, selecionaram-se a divergência de ideias; Querer fazer duas coisas e elas não se cruzarem, ou se cruzarem erradamente; Tudo que está diverso à pacificação; Não conciliação das diferentes formas de pensar; Não conseguir fazer alguma coisa; No trabalho, você não conseguir fazer aquilo que você planejou; Quando não se consegue chegar a um denominador comum; Divergência de interesses, ponto de vista, objetivos; Eu me cobro mais; Até desse desânimo eu me cobro; A outra pessoa pode não aceitar as nossas ideias, nossas teorias e viceversa;

Como exemplo dos conceitos levantados na opinião das participantes do estudo, conflito é "quando existem divergências de opiniões, ideias... Seja o que 
for... E que não se chega a um... A um denominador comum. Quando as pessoas não conseguem conciliar as diferentes formas de pensamento." (GM2)

\subsubsection{O conflito pode ser gerado, independente do outro, pela própria personalidade do individuo}

Verificou-se que, por vezes, o conflito é algo nato, em razão do caráter e da personalidade do indivíduo. Que a pessoa perfeccionista, metódica carrega em si o conflito latente quando não consegue concluir ou realizar alguma tarefa, algo que se propôs, independente de qual seja o fato que a impediu nessa realização, o que gera a própria cobrança. Essa realidade pode ser percebida nos Quadros 11 e 12 (p. 88-90), respectivamente.

Há a percepção, ainda, de que o importante é que se busquem soluções, sem a absoluta necessidade de identificar de onde ou de quem partiu o conflito (GM6, QUADRO 11, p. 88). O diálogo, mais uma vez, se transforma em mediador de conflitos para a maioria das gerentes entrevistadas, independente de ser no seio familiar ou não, quando o "diálogo estimula um relacionamento franco e aberto e cria uma relação de confiança, contribuindo para evitar a interferência de conflitos entre a prática gerencial e as relações de família" (SILVA E ROSSETTO, 2010, p. 52). Identifica-se uma cobrança por parte delas com relação ao trabalho e à conclusão de suas tarefas diárias, o que pode vir a gerar o conflito pessoal.

E quando o conflito parte de algum fator externo, há consciência da necessidade de se por no lugar do outro para possibilitar uma visão diferenciada dele (GM2, QUADRO 11, p. 88). É primordial haver equilíbrio entre as partes.

Pelo compreendido, o conflito é intrínseco à diversidade presente na sociedade, em todos os sentidos, sendo vista como um dos fatos geradores de conflito, a não ser que a pessoa se permita ser apenas um expectador não participante do que ocorre na sociedade (GM5, idem).

A existência do conflito para as gerentes estudadas não prescinde de um fator específico, não sendo levantado o problema de ele ser originário da família ou do trabalho. O conflito pode surgir da própria cobrança que se é imputada, ou da necessidade em se extravasar sentimentos, emoções. 
A aceitação do conflito como algo saudável e essencial, desde que ponderado, também se encontra patente entre os discursos, quando é entendido que na divergência de ideias, ao se juntarem esses conceitos diversos, pode-se criar um novo entendimento a respeito do que esteja em discussão, surgindo uma nova ideia e, assim, contribuir para a expansão do conhecimento (GM4, ibidem). Essa afirmação vem comprovar o entendimento de Robbins (2002) quanto aos efeitos positivos do conflito a partir do momento em que se alcance uma solução integrada do problema, beneficiando as partes.

Entre os temas levantados, estão: A falta de tolerância; Aceitar a outra parte; Incompreensão; É difícil saber de onde partiu o conflito; Pode acontecer das duas formas (provocado por uma ou outra parte); Prioridades; Procuro me colocar no lugar da outra pessoa; Aceitação; Conflito é essencial; O conflito, ele é necessário; Tem que ter ideias contrárias, até porque pra você chegar a um denominador comum; O conflito existe de todos os lados; Divergências de opiniões; Sempre existe (conflito); Diversidade de princípios, pensamento, criação; Desinteresse; Disposição para briga; Necessidade de extravasar emoções; Dependência entre pessoas; Cada um é criado de um jeito, cada um tem um pensamento; O essencial é a aceitação; É o quanto você está disponível a aceitar a diferença do outro; O quanto você está maleável a, também, mudar um pouco.

Para corroborar com o entendimento de que o fato gerador do conflito decorre da diversidade, ou seja, de uma "[...] relação antagônica a respeito de um mesmo objetivo...", conforme Touzard (1981, p. 64), e que a busca de uma solução através do diálogo ainda é a melhor forma para lidar com ele, transcreve-se a verbalização abaixo:

"O conflito ocorre de várias maneiras, já que cada indivíduo possui seus
princípios, conhecimentos, interesses, ponto de vista etc. O importante é o
diálogo, e a partir daí encontrar um ponto de equilíbrio. O conflito surge de
algum problema e que não basta identificar de onde surgiu e sim focar na
solução, até porque, com os conflitos sempre há oportunidades de reflexão
e crescimento." (GM6).

Enfatizando a existência do conflito como algo saudável, confirmando as abordagens feitas por Robbins (2002) sobre o conceito de conflito, conforme citado anteriormente, a GM 4 defende que

"[...] Acho que o conflito ele é necessário [...] Pra se viver em um ambiente, seja ele qual for, você tem que ter um conflito, tem que ter ideias contrárias, até porque pra você chegar num denominador comum. Não tem como todo mundo ter uma ideia igual. Porque se fosse também seria muito sem graça. 
E acaba que você também não expandiria os seus conhecimentos [...]

Então, acho que pra... O conflito é essencial. Claro que ponderado, né?..."

\subsection{Identificando as formas encontradas para lidar com o conflito}

Para conhecer e entender as formas como essas mulheres conseguem administrar o tempo de dedicação aos diversos papéis que the são imputados e continuarem desenvolvendo o seu lado profissional, bem como minimizando ou evitando sua incidência e consequências, os itens abaixo buscam esclarecer essa realidade, cujas verbalizações se fazem presentes no Quadro 14 (p. 94).

\subsubsection{Para conseguir compatibilizar família e trabalho é fundamental manter-se um equilíbrio entre essas duas instâncias da vida}

Silva e Rossetto (2010, p. 4) perceberam que "O trabalho e a família estão interconectados", e, citando Fu \& Shaffer (2001), constataram que "manter um relacionamento harmonioso entre essas duas dimensões beneficia as pessoas e a organização".

Essa realidade também foi identificada no relato da participante do estudo GM4 ao afirmar que, em razão da quantidade de horas dispendida ao trabalho, as pessoas passam a ter uma relação "meio familiar" com os colegas de trabalho, e "traz as pessoas da sua família pra esse convívio". Isso demonstra a possibilidade de equilibrarem-se harmonicamente família e trabalho, minimizando a interferência entre as duas instâncias de sua vida.

Quanto à interferência do trabalho na vida familiar, apesar de uma ou outra participante afirmar que tem procurado administrá-la e controlar para que ela não ocorra com frequência, na maioria das vezes, registra-se essa interferência. Quanto a alguma interferência da família sobre a vida profissional, também foi admitida, mesmo que de forma discreta.

Exceções dessas interferências foram feitas pela GM5 quando reforça que "Ah, não tenho família, ninguém depende de mim"; pela GM2, que ao chegar em 
casa, em razão de ter crianças pequenas para cuidar, se desliga do trabalho, e pela GM6, por morar só "não há interferências nesse sentido".

Reconhecem-se pelos temas levantados que, mesmo em graus diferenciados, elas se fazem presentes: Dificuldade maior é conseguir conciliar trabalho e casa; É só um tempinho à noite; Até no fim de semana ainda tenho reflexo do trabalho; Eu deveria desligar mesmo; Quanto eu 'tou' no trabalho, eu procuro focar o meu trabalho; Trazendo do trabalho para casa; De casa pro trabalho, às vezes; O cérebro fica trabalhando; Eu tenho acordado assim de madrugada; Porque eu não quero interferir muito no trabalho; Não deixo que interfira muito não; Porque a gente não é um ser humano em casa e outro no trabalho; Não consigo (desligar do trabalho); Não "tou" conseguindo me desligar; Até nas férias eu não me desligo muito; Mas eu ainda levo (do trabalho para casa); Não desligo de jeito nenhum; Eu "tou" melhorando, mas ainda falta muito; Eu me dedico mais ao trabalho; Eu não tenho esse tipo de cobrança; Você não sai daqui seis horas e desligo o botão; Não tem cristão que desligue esse troço; O cérebro é um só; Eu me desligo, exceto se for uma coisa muito grave; Quando eu chego em casa acabou; Nem sempre, muitas vezes causa insônia.

A verbalização abaixo permite o reconhecimento da interferência existente, e baliza a impressão de Silva e Rossetto (2010, p. 11) com relação às "reações emocionais, cansaço físico etc." a que estão sujeitas, também, as gerentes:

\footnotetext{
"[...] Eu tenho acordado assim de madrugada e não consigo mais dormir. Porque, assim, o cérebro fica trabalhando... Vem à tona. Se eu lembrar de uma coisinha só, aí parece que vem uma cadeia, uma sequência de coisas que surgem, você já não dorme mais. Resultado: você já passou o dia... Já começa trabalhar o dia cansada [...] Ultimamente tem acontecido muito isso." E complementa: "Às vezes é complicado compatibilizar. De casa pro trabalho, às vezes [...] porque eu não quero interferir muito no trabalho... Deixo pra final de semana. De qualquer maneira existe uma certa interferência, porque a gente não é um ser humano em casa e outro no trabalho [...] Eu tento conciliar sim." (GM3).
}

\subsubsection{A dedicação ao trabalho é fator de privação ao convívio familiar, gerando cobrança pessoal}

Percebeu-se ao longo do estudo que as gerentes, em função da dedicação maior ao trabalho, possuem um sentimento de cobrança muito forte, haja vista, não raras vezes, sacrificarem a vida pessoal em favor da vida profissional. 
Quadro 4 - Consequências dos Conflitos Experimentados pelas Gerentes

\begin{tabular}{lll}
\hline \multicolumn{1}{c}{ CATEGORIAS } & SIGNIFICADOS \\
\hline $\begin{array}{l}\text { Consequências dos conflitos } \\
\text { vividos no âmbito profissional; }\end{array}$ & $\begin{array}{l}\text { Necessidade de ajuda profissional (terapeuta). Problemas } \\
\text { de saúde (estresse, insônia). Sentimento de inadequação. } \\
\text { Cobrança excessiva. Desgaste emocional. Cansaço. }\end{array}$ \\
$\begin{array}{lll}\text { Consequências dos conflitos } \\
\text { profissionais sobre a vida em } \\
\text { família; }\end{array}$ & $\begin{array}{l}\text { Falta de Disposição. Incapacidade para desenvolver o } \\
\text { trabalho doméstico. Falta de tempo para si e para a } \\
\text { família. Necessidade de estudar na hora do lazer. } \\
\text { Privação do convívio familiar. Dificuldade em conciliar } \\
\text { trabalho e casa. Ressentimento do tempo "roubado" da } \\
\text { família. Necessidade de buscar ajuda nos problemas com } \\
\text { os filhos. Cuidados com a saúde relegados ao segundo } \\
\text { plano. }\end{array}$
\end{tabular}

Consequências dos conflitos Não foi identificado conflito na vida pessoal das gerentes pessoais sobre o trabalho que traga consequências para o desenvolvimento de seu trabalho. Uma ou outra interferência foi admitida de forma discreta, mas que não compromete a vida profissional.

Dentre os motivos que originam o conflito trabalho/família, independente de gênero, pode-se afirmar que esse se dá pelo "tempo dedicado ao exercício de papéis no trabalho e na família, à incompatibilidade de interesses e às divergências de percepção e de visão entre os agentes envolvidos" (SILVA E ROSSETTO 2010, p. 7).

Também foi possível identificar que a dedicação excessiva a um dos papeis desempenhados e a respectiva cobrança não são unânimes entre as gerentes. Ora o fator determinante foi o estado civil, ora foi uma conscientização de que cada qual tem o seu momento, representado pelo transcrito no Quadro 13 (p. 92).

Portanto, julga-se haver um equilíbrio entre as participantes quanto ao tempo dispendido para o trabalho e a família, mas que a cobrança, tanto profissional quanto pessoal está instalada no cotidiano do gênero feminino nesse contexto, quando as afirmações no Quadro 12 (p. 90) caracterizam essa cobrança.

Relativamente à cobrança existente, não se retratou somente partindo delas próprias. Ela acontece no ambiente de trabalho e surge, também, por parte da própria família que se ressente do tempo "roubado" para sua convivência. Igualmente, em razão do equilíbrio entre essas duas instâncias, ou pelo fato de ser solteira, não há cobrança, ou ela não é constante, motivo pelo qual não se irá apresentar verbalização dessa ausência. 
Para descrever o dispêndio de tempo para uma ou outra face da vida, os temas a seguir o relatam: Eu realmente me dedico mais ao trabalho; O tempo maior é no trabalho; No final de semana eu sempre pego um tempinho pra estudar; Acho que eu equilibro; Não me dedicar a uma coisa só; Depende do que me requer mais a atenção; Cada um com seu horário de dedicação; É equilibrado; Trabalho.

O que retrata a dedicação maior ao trabalho está contido no discurso da GM1, quando diz que "É o trabalho né? Embora eu esteja errada, eu acho... Preciso mudar, mas realmente eu me dedico mais ao trabalho".

Contrapondo-se ao afirmado por ela, o que permitiu que se entendesse como equilibradas as opiniões, a GM2 foi enfática ao dizer que

\begin{abstract}
"Ah, dedicação... Cada um com seu horário de dedicação. Não tem... É equilibrado. Não sou aquela... Aquela mãe que exagera, passa o dia telefonando pra saber se está tudo bem, né? E também não sou aquela profissional que leva trabalho pra casa. De chegar em casa e não dar atenção à família, e só pensar... Eu tento, tento dar uma equilibrada nas coisas."
\end{abstract}

Para ressaltar a cobrança em suas vidas, os temas destacados foram: Minha irmã e minha mãe, elas cobram muito; Às vezes (me cobro); Me cobro bastante; É ele (marido) que briga pra caramba; Ele (marido) não aceita não; A gente é cobrado pelos dois (marido e filho); Não tem um mais outro menos, não; Me cobro; O tempo "tá" curto; Todo mundo é resolvido, não existe cobrança; Eu não. Cobrar pra que? Não moro com família; Tanto os filhos como o marido também; Eles sempre cobram; Pelo menos, no momento não (me cobro).

A verbalização que caracteriza a cobrança familiar veio do discurso da GM1, quando diz que

"É... No caso marido, né? É com certeza. É ele que briga pra caramba... Muito, muito [...] Por eu chegar um pouquinho mais tarde... Por, às vezes, ele me telefonar aqui e eu não poder atender, [...] Ele não aceita não. Nem parece que trabalha na mesma empresa.

No caso da própria cobrança, a GM3 destaca que

"Me cobro... É, porque... É isso que eu 'tou' te falando... O tempo tá curto pra atender as duas... as duas coisas... Então, se eu tivesse assim, um pouquinho mais... Acho que eu poderia dedicar um pouco mais pros meus filhos... Pra família. 


\subsubsection{Dentre os meios para administrar o conflito, ainda é o diálogo a forma mais eficiente de mantê-lo sob controle, mesmo que outros ajustes e providências sejam necessários}

Para expressar as formas encontradas e os ajustes a serem feitos para melhor administrar o conflito, a adaptação, o diálogo, a ajuda profissional e a elaboração de um planejamento se fazem primordiais.

Essa indicação pode ser sustentada por Silva e Rossetto (2010, p. 12) quando afirmam que "programas de apoio psicológico, incentivo ao diálogo do tema nas relações interpessoais, planejamento e organização da agenda de trabalho, entre outros" são ações que precisam ser implementadas para "minimizar os conflitos na relação trabalho e família".

Em contrapartida, foi ressaltado por uma das participantes não haver necessidade de ajustes ou administração por não entender conflituosa essa relação, uma vez que, no horário de trabalho, ela executa as atividades pelas quais é paga; depois do horário de trabalho, os seus compromissos são cumpridos sem qualquer dificuldade.

Os temas surgidos nessa etapa foram: Sempre "tou" fazendo ajustes; A gente vai levando; Às vezes deixo um pra "tá" fazendo o outro; Eu sempre "'tou' matando" alguém; Eu administro; Eu acho muito difícil; Comecei a fazer terapia agora; Sozinha quase impossível; Com o diálogo; O trabalho sempre te exige o máximo; $O$ trabalho é puxado e o melhor a fazer é adaptá-lo a outras necessidades; Um planejamento mais adequado; Planejar melhor o tempo.

Dos discursos apresentados, a postura da GM4 exemplifica a forma encontrada para administrar o conflito.

"[...] Sempre 'tou' fazendo ajustes, mas nunca... Nunca dá 100\% certo, mas a gente vai levando conforme... Conforme o tempo, né? Se eu tenho tempo, tenho que... Sempre faço concessões, né? Às vezes deixo um pra 'tá' fazendo o outro, né? [...] A gente vai sempre matando alguma coisa da rotina pra 'tá' dirimindo aquela outra que você deixou de fazer antes. É isso... Eu sempre 'tou' matando alguém...."

Sendo assim, cada qual procura administrar e ajustar à sua maneira, dependendo de sua realidade. Ora solicitando ajuda, ora planejando o tempo disponível para as diversas atividades que fazem parte do seu cotidiano; ora, simplesmente se dedicando a uma ou a outra em seus horários respectivos. 
Percebeu-se que a face "boa" ou "má" do conflito, conforme depreendido de Robbins (2002), será dependente não somente da eficácia com que esse seja gerido pela organização, mas também pelo próprio indivíduo. 


\section{CONCLUSÕES E RECOMENDAÇÕES}

Esse trabalho buscou conhecer e entender o conflito família/trabalho no gênero feminino, mais precisamente entre mulheres gerentes em uma agência bancária. Durante a realização das entrevistas não foi identificado que, por serem mulheres em cargo de chefia, isso implique discriminação por parte dos homens gerentes, nem que tal condição seja questionada com relação à capacidade, conhecimento e desenvolvimento do trabalho. Apesar de não se ter entrado no mérito das questões, entende-se que essas poderiam ter sido exploradas mais profundamente.

Sobre o papel da mulher na sociedade, percebeu-se que está presente o sentimento intrínseco de proteção e de agregadora que levam consigo tanto na vida familiar quanto profissional. Destaca-se que suas responsabilidades domésticas e relações familiares não as limitam na busca da capacitação e aperfeiçoamento profissional, mesmo que para isso seja preciso aceitar e sofrer, além das pressões profissionais, com a sobrecarga que as atividades familiares Ihes imponham.

No sentido da limitação na busca da capacitação, o fato de a maioria das participantes de estudo ser solteira pode ter "mascarado" em parte essa afirmação. Tal fato demandaria um estudo mais aprofundado, e com um número maior de mulheres casadas, para comprovar essa conclusão.

Está patente, ainda, que os diversos papéis a que estão sujeitas são interligados e, algumas vezes, se sobrepõem uns aos outros formando um só. A pesquisa indicou que a satisfação que demonstram para com o trabalho não foi sentida em função do cargo que ocupam, e sim pelo simples fato de gostarem do que fazem e poderem atender as demandas que se apresentam. De onde se conclui que, mais uma vez, o sentimento afetivo não está ausente nas atividades profissionais.

Apesar de a faixa etária não ter variado tanto quanto se pensou e gostaria a princípio, para que se alcançasse maior diversidade a respeito dos temas abordados, inclusive pelo fator maturidade, perceberam-se visões muito particulares nos diversos temas que compuseram a entrevista.

Relativamente ao trabalho, a identificação com ele é unânime, confirmando ser ele primordial para o sentimento de utilidade e completude do indivíduo. Dessa 
forma, as pressões diárias sofridas não descaracterizam ou minimizam esse sentimento, conforme depreendido da literatura consultada.

Quando da identificação do conflito existente, entende-se que esse tomou um novo rumo ao ser percebido que, muitas vezes, ele surge mais de questionamentos pessoais do que do ambiente externo, tendo em vista a cobrança que fazem a si mesmas.

Pensa-se que esse novo rumo tenha comprometido, em parte, o proposto inicialmente para desenvolvimento da pesquisa, ou seja, identificar qual das dimensões gera o conflito. Entretanto, não se descarta o conflito existente pela diversidade existente na sociedade, em todos os seus aspectos, inclusive pelo choque de opiniões ou interesses que, invariavelmente, passa pelo diálogo, pela convivência e comprometimento entre os atores envolvidos para se chegar a um consenso.

A bidirecionalidade do conflito, mesmo explicitada, não foi vista como sendo um problema específico a ser tratado e sim como situações que devam ser administradas e ajustadas. Percebe-se que pode ter havido falha nessa exploração.

O diálogo, também no presente trabalho, foi entendido como a peça chave da boa convivência, tanto na vida profissional quanto na pessoal, para a superação de conflitos, ou mesmo para se evitar que eles surjam. Nesse sentido, ao se transformar em apoio, em qualquer de suas formas e vindo das mais diferentes pessoas, é primordial para o bem-estar das participantes do estudo, sendo, ainda, a força motora de toda e qualquer atividade realizada.

Constata-se que a família desempenha um papel máximo em importância e é prioridade na vida do indivíduo, mesmo que isso implique em sacrifícios próprios. Apesar da quantidade de participantes de estudo, em razão dos discursos, não restou dúvidas quanto a esse entendimento.

Entendeu-se que não há uma "receita" para lidar com as interferências do conflito, sendo necessário buscar meios para administrá-lo. Tais meios podem incluir separar as duas esferas, com momentos próprios para cada uma delas, ajuda externa de profissionais, adaptações ou ajustes diários.

A quantidade de participantes do estudo e a escolha por um cargo específico, assim como faixas etárias tão próximas, e com realidades tão distintas no tocante à família, ao trabalho e à percepção, pode ter prejudicado a coleta de informações que permitisse maior aprofundamento e abrangência das questões aqui tratadas. 
Percebeu-se que, talvez, o ideal seria não ter restringido tanto a população pesquisada, ou, ainda, focar tão somente as variáveis que surgiram do problema de pesquisa.

Considera-se, também, a possibilidade de aplicação de outra metodologia para uma melhor exploração do tema. Haja vista que a metodologia utilizada não é única e exclusiva, poderiam surgir outras variáveis em contexto diferenciado que influenciem o conflito, a exemplo do estilo de liderança, pessoas ou equipes direta ou indiretamente envolvidas, a cultura organizacional e a empresa, necessitando de maior detalhamento e outros procedimentos, sejam eles qualitativos ou quantitativos, para melhor conclusão do trabalho.

As conclusões a que se chegaram neste trabalho não permitem generalizar para outros cargos, ou até mesmo para cargo semelhante em outras agências e diferentes setores do mercado de trabalho, tendo em vista a sua peculiaridade em contexto pré-definido.

Alia-se ao descrito a dificuldade em encontrar literatura pertinente que pudesse embasar mais consistentemente o presente trabalho e promover melhor discussão sobre o conflito família/trabalho. A escassez de discussão sobre o tema levantado nesse trabalho, com poucos artigos, periódicos ou livros que enfoquem a família ou o trabalho como geradores de conflito na vida de mulheres que desenvolvem atividades fora do lar foi profundamente sentida. Esse fato pode ser justificado pela sua recente entrada no mercado de trabalho, nos diferentes e diversos setores aonde elas começam a marcar presença.

Acredita-se que o trabalho em comento possa servir de base para despertar no indivíduo uma reflexão sobre os diversos papéis que ele desempenha na sociedade, organizando e administrando essas dimensões para que haja uma convivência harmônica entre elas, ou mesmo buscando outra atividade que the possibilite essa harmonia.

De igual forma, é um indicativo da importância de tomada de consciência organizacional quanto ao conflito existente, que poderia trazer para si parte da responsabilidade em fornecer as ferramentas necessárias para ajudar seus funcionários na transposição desses conflitos, sejam pessoais ou profissionais.

Ao realizar esse trabalho, vê-se, ainda, a possibilidade de incentivar outros estudos com grupos diferenciados de mulheres, seja em cargos de liderança ou não, 
no intuito de conhecer a realidade diária do gênero que exerce diferentes papéis no seu cotidiano, muitas delas cumprindo tripla jornada.

Por esse motivo, considera-se que a pesquisa deva ser continuada suprindo as lacunas identificadas, abrangendo, mesmo que enfoque a mesma categoria aqui presente, uma população maior de mulheres e de outros setores no mercado financeiro, corrigindo as falhas identificadas. A personalidade, o estágio na carreira, a diversidade cultural e um novo contexto são variáveis consideráveis para novo estudo.

A viabilidade de direcioná-lo para outro setor produtivo do mercado que se entenda mais crítico quanto à equidade de gênero, possibilitaria riqueza de detalhes e forneceria maior conhecimento da realidade enfrentada pela mulher no atual cenário, tanto nacional quanto internacional.

Entrevistas mais focadas no tema, para não darem margens a muitas divagações e informações que, mesmo correlatas com o conflito vivido, contribuiriam para uma conclusão mais precisa.

No que diz respeito à Gestão de Pessoas, vê-se a necessidade de que as próprias organizações, junto ao setor de Gestão de Pessoas, busquem maiores informações sobre a existência de conflito em seu ambiente organizacional. Essa medida permitiria maior conhecimento sobre variáveis que possam evitar ou minimizar seu aparecimento, tanto no nível familiar quanto no profissional, criando um ambiente mais saudável e de maior produtividade para seu corpo funcional, e, consequentemente, para a empresa, quando a equidade de gênero também estaria preservada.

Compreende-se, complementarmente, que o conflito família/trabalho vivenciado por mulheres em cargo de liderança, depois de identificado, poderá embasar futuros programas de desenvolvimento de competências e atividades, de qualidade de vida, entre outros, que contemplem minimizar o conflito existente, como também ajudá-las a encontrar meios para melhor administrá-lo, o que pode vir a aumentar a produtividade e reduzir o absenteísmo e o sofrimento que dele resultam. 


\section{REFERÊNCIAS}

ALENCAR, E. Introdução à metodologia de pesquisa. Lavras: UFLA, 1999.

ARANHA, M. L. de A., \& MARTINS, M. H. P. FILOSOFANDO: Introdução à Filosofia. $2^{\underline{a}}$ ed. São Paulo: Moderna, 1999.

BARRETO, A. V. P.; HONORATO, C. de F. Manual de sobrevivência na selva acadêmica. Rio de Janeiro: Objeto Direto, 1998.

BLOOM, H. Shakespeare: A invenção do humano. Trad. José Roberto O'Shea. Rio de Janeiro: Objetiva, 2000.

BRUSCHINI, C., \& LOMBARDI, M. R. (2002). Trabalhadoras brasileiras dos anos 90: mais velhas e mais instruídas. Revista Mulher e Trabalho. Disponível no site http://www.fee.rs.gov.br/sitefee/download/mulher/2002/artigo5.pdf - Acesso em 3 jul. 2010.

DURKHEIM, E. As regras do Método Sociológico. São Paulo: Cia Ed. Nacional. 1979.

GAIARSA, J. A. O espelho mágico: um fenômeno social chamado corpo e alma. 10 ed. São Paulo: Summus, 1984.

GIDDENS, A. Modernidade e Identidade Pessoal. Celta Editora, 1997.

GIL, A. C. Métodos e técnicas de pesquisa social. São Paulo: Atlas, 1999.

Atlas, 2002.

. Como Elaborar projetos de pesquisa. $4^{\underline{a}}$ ed. São Paulo:

GODOY, A. S. Introdução à pesquisa qualitativa e suas possibilidades. In:

Revista de Administração de Empresas. São Paulo: v. 35, no. 2, p. 57-63, Abr. 1995.

KOLOUSTIAN, S. M. (org.). Família Brasileira, a Base de Tudo. São Paulo: Cortez, 1988. Brasília, DF: UNICEF.

LINDO, M. R.; CARDOSO, P. M.; RODRIGUES, M. E.; WETZEL, U. Vida Pessoal e Vida Profissional: os Desafios de Equilíbrio para Mulheres Empreendedoras do Rio de Janeiro. RAC-Eletrônica, v. 1, ㄲo. 1, art. 1, p.1-15, Jan/Abr. 2007. Disponível no site http://www.anpad.org.br/periodicos/arq pdf/a 621.pdf - Acesso em 10 Abr. 2010.

LÜDKE, M; ANDRÉ, M. E. D. A. Pesquisa em educação: abordagens qualitativas. São Paulo: EPU, 1986.

MONTAIGNE, M. Ensaios. Trad. Sérgio Milliet. São Paulo: Editora Nova Cultural Ltda., v. 1, 1996. 
MORENO, J. L. Psicodrama. $2^{\text {a }}$ ed. São Paulo: Cultrix, 1978.

NEVES, J. L. Pesquisa qualitativa - características, uso e possibilidades. In: Cadernos de pesquisa em Administração. São Paulo: v. 1 ํo. 3, 2ํsemestre, 1996.

QUEIROZ, M. I. P. Relatos orais: do "indizível" ao "dizível”. In: VON SIMSON, O. M. Experimentos com histórias de vida. São Paulo: Vértice, p. 14-43, 1988.

QUELHAS, F. de C. Mulheres Executivas no Mercado de Trabalho. VI Congresso Nacional de Excelência em Gestão. 5, 6 e 7 de Agosto de 2010. Disponível no site http://www.excelenciaemgestao.org/Portals/2/documents/cneg6/anais/T10 025412 13.pdf - Acesso em 04 Out. 2010.

RAHIM, M. A. Managing conflict in organizations. $3^{\underline{a}}$ ed. Westport, CO: Quorum Books, 2001.

RAUEN, F. J. Elementos de iniciação à pesquisa. Rio do Sul, SC: Nova Era, 1999.

ROBBINS, S. P. Comportamento organizacional. 9 $9^{a}$ ed. São Paulo: Prentice Hall, 2002.

SENNETT, R. A Corrosão do caráter: consequências pessoais de trabalho no novo capitalismo. Rio de Janeiro: Record, 2008,

SILVA, A. B. da; ROSSETTO, C. R. Os Conflitos entre a Prática Gerencial e as Relações em Família: uma Abordagem Complexa e Multidimensional. RAC, Curitiba, v. 14, no. 1, art. 3, p. 40-60. Jan/Fev./2010. Disponível no site http://www.scielo.br/scielo.php?pid=S1415-65552010000100004\&script=sci arttext _Acesso em 25 Abr. 2010.

TOLEDO, S. Carreira e Identidade: Reflexos das Exigências Mercadológicas na Vida Pessoal e Profissional dos Jovens Executivos de Empresas Multinacionais. Disponível no site http://www.anpad.org.br/enanpad/2006/dwn/enanpad2006-gpra-1280.pdf - Acesso em 10 Abr. 2010.

TOUZARD, H. La mediación y la solución de los conflictos. Barcelona: Editorial Herder, 1981.

TRIVIÑOS, A. N. S. Introdução à pesquisa em ciências sociais: a pesquisa qualitativa em educação. São Paulo: Atlas, 1987.

VASCONCELOS, A. F. Qualidade de Vida no Trabalho: origem, evolução e perspectivas. Disponível no site http://www.ead.fez.usp.br/cad-pesq/arquivos/v081art.03.pdf - Acesso em 11 Abr. 2010.

VERGARA, S. C. Métodos de Pesquisa em Administradora. São Paulo: Atlas, 2005. - Texto fornecido pela Supervisão de Psicologia do Curso de Administração à Distância. Universidade de Brasília, 2007. 
ZANELLA, L. C. H. Metodologia da pesquisa. Secretaria de Educação à Distância do Ministério da Educação (UAB/SEAD/MEC). Curso de Graduação em Administração à Distância, 2006. 
APÊNDICES 


\section{APÊNDICE 1 - CARTA DE APRESENTAÇÃO PARA A INSTITUIÇÃO BANCÁRIA}

Brasília-DF, 03 de Julho de 2010.

Ao Banco Sudoeste

Brasília-DF

Prezado Senhor,

Eu, NÁDIA SANT' ANNA BRANCO, estudante do curso de Graduação em Administração à Distância pela Universidade de Brasília, estou realizando uma pesquisa sobre o Conflito Família/Trabalho. O título do trabalho é Vida Pessoal $\mathrm{x}$ Vida Profissional: o Difícil Caminho para o Equilíbrio, em sua fase atual.

Esse trabalho tem por objetivo conhecer e entender o conflito família/trabalho na vida de mulheres empreendedoras. No caso dessa agência, mulheres que desenvolvem o cargo de gerente nos diversos segmentos existentes. Essa pesquisa possui natureza qualitativa e será analisada pelo método exploratório-descritivo. Para tanto, é necessário que eu realize entrevista com seis funcionárias desse nível operacional.

Ciente da necessidade em se respeitar o horário de expediente bancário, gostaria de solicitar sua especial atenção no sentido de permitir meu acesso às funcionárias para realização das entrevistas, as quais poderão ocorrer no prazo compreendido entre $1^{\circ}$ de Agosto a $1^{\circ}$ de Setembro, com dias a serem estabelecidos por V.Sa., no período das 9:00hs às 10:00hs.

Sendo só o que se apresenta para o momento, antecipadamente agradeço.

Atenciosamente,

Nádia Sant' Anna Branco

Contatos: (61) 3361-0181 / 9909-9069

E-mail: nadiasneves@gmail.com 


\title{
APÊNDICE 2 - CARTA DE APRESENTAÇÃO PARA AS PARTICIPANTES DA PESQUISA
}

\author{
Brasília-DF, 03 de Julho de 2010.
}

Prezada Senhora,

Eu, NÁDIA SANT' ANNA BRANCO, estudante do curso de Graduação em Administração à Distância pela Universidade de Brasília, estou realizando uma pesquisa sobre o Conflito Família/Trabalho. $O$ título do trabalho é Vida Pessoal $x$ Vida Profissional: o Difícil Caminho para o Equilíbrio, em sua fase atual.

Esse trabalho tem por objetivo conhecer e entender o conflito família/trabalho na vida de mulheres empreendedoras e como elas lidam com ele. A pesquisa possui natureza qualitativa e será analisada pelo método exploratório-descritivo. Para atender ao objetivo da pesquisa, é fundamental a realização de uma entrevista com seis funcionárias, no nível de gerência, e sua duração obedecerá ao tempo máximo de 40 minutos. A realização de uma segunda entrevista será avaliada posteriormente, mas, a priori, não se entende como necessária. A entrevista será agendada com antecedência, dentro da disposição de cada entrevistada. A intenção da mesma é conhecer e entender, sob a ótica da entrevistada, as experiências vividas enquanto mulheres empreendedoras e, ao mesmo tempo, responsáveis pelas atividades domésticas que lhe são atribuídas no cotidiano. As informações obtidas serão mantidas em sigilo.

Para garantir a realização da pesquisa, solicito sua participação na entrevista que será gravada e transcrita, para garantir a fidelidade do discurso. Depois da transcrição será submetida à sua avaliação para confirmação das informações prestadas. Como posto anteriormente, havendo necessidade de nova entrevista no decorrer da análise dos dados, quanto a esclarecimento ou complementação do discurso primeiro, novo contato será feito.

Sendo só o que se apresenta para o momento, antecipadamente agradeço a participação.

Atenciosamente,

Nádia Sant' Anna Branco

Contatos: (61) 3361-0181 / 9909-9069

E-mail: nadiasneves@gmail.com 


\section{APÊNDICE 3 - ROTEIRO DE ENTREVISTA}

Cargo:

Idade:

Estado Civil:

Filhos, idades:

Tempo de trabalho:

\section{Conhecendo a realidade pessoal e profissional da participante do estudo}

- Fale sobre sua família e histórico de vida.

- O que significa família e qual a sua importância para você?

- O que você percebe como mais importante na vida familiar? (diálogo, comprometimento, aceitação, apoio emocional).

- Você organiza o seu dia e a vida familiar? Possui uma rotina? De que forma?

- O que você prioriza no cotidiano em família? De que forma você gerencia o seu tempo?

- O tempo para você tem mais a ver com qualidade ou quantidade?

- Defina a mãe e a mulher.

- O que mais interfere em sua vida pessoal?

- Há apoio da família com relação ao trabalho (marido, filhos)?

- O que contribui para o seu bem-estar em família?

- Fale sobre sua trajetória profissional? Sempre trabalhou no Banco ou teve trabalhos anteriores em organizações de outros setores. Quanto tempo no cargo?

- Qual é o perfil exigido para o cargo? Você corresponde ao exigido em todos os sentidos?

- O que representa o trabalho para você? Qual a sua identificação com ele?

- É possível adotar uma rotina em seu trabalho? Você o faz? Como?

- Como é a sua convivência com os colegas de trabalho? Há compartilhamento de emoções e pensamentos ou cada um fica na sua? (Comportamento: Competição, colaboração, compromisso, acomodação, variáveis pessoais).

- O que é reconhecimento e aceitação para você? 
- Defina a gerente!

- Como você vê a qualificação profissional?

- O que mais interfere no seu trabalho?

- Você se "desliga" depois de cumprido o período de trabalho?

\section{Descrevendo o conflito vivido}

- Qual é a sua ideia de conflito?

- O que pode gerar conflito em uma relação? (Aceitação do outro, divergência de interesses, ideias)

- O conflito, via de regra, parte de algum sentimento seu ou é provocado por outrem??

- Há cobrança no ambiente familiar? Quem cobra mais sua presença (Marido, filhos)?

- E no ambiente de trabalho?

- Qual o seu sentimento quanto à realização pessoal? O que mais a realiza?

\section{Identificando as formas encontradas para lidar com o conflito}

- Como você compatibiliza a família e o trabalho?

- Você percebe que se dedica mais a qual das duas facetas de sua vida (família ou trabalho)?

- Você se cobra, no caso, pela falta de tempo dedicado à família e/ou ao trabalho?

- Você sente, em algum momento, que sacrifica a vida pessoal em favor da profissional?

- Como você administra essa cobrança? Que ajustes podem ser feitos para manter o equilíbrio? 


\section{APÊNDICE 4 - Quadro 5 - A Família}

\section{SIGNIFICADO DA FAMÍLIA}

Família é a coisa mais importante do mundo;

Família eu acho que é a base para a vida de todos nós. Família é o apoio, é segurança, é companheirismo. Uma família unida é muito importante para o ser humano se sentir, se sentir seguro e conseguir, poder oferecer no futuro uma família para seus filhos também.

Família significa um porto seguro. É o que há de melhor num ser humano [... sem a família o ser humano fica meio que perdido... Meio que solto. Não tem um norte

Família [...] é o centro da vida. [...] Ela é que te dá o pontapé inicial. [...] Família é essencial, é o principal... Alicerce;

Família é o lugar onde você nasce, cresce, aprende e sai fora. E só mantém o relacionamento assim, cordial, de amigo, sem depender de ninguém. [... Família é o lugar onde você cria. É o ninho. Família eu falo, assim, pai, mãe, irmãos, assim, né?

Família significa origem. A minha família apesar de pequena é o meu refúgio.

\section{BASE E IMPORTÂNCIA}

DISCURSO

[...] É realmente a minha família que me dá força para aguentar isso aqui; O diálogo, porque através do diálogo vem a ajuda... Então é isso que a minha família procura fazer uns com os outros. Diálogo e ajuda;;

O diálogo, porque o diálogo leva ao entrosamento; através do diálogo que chega ao entendimento, ao auxílio. É 0 diálogo, não só pra família, mas pra vida toda;

É o que faz com que a gente levante todo dia e venha trabalhar. [...] Vai aprendendo com os filhos [...] E na vida familiar é esse apoio, essa troca. [a família] te dá um apoio.. Te dá um ombro amigo.

É um equilíbrio... Você tem

Um relacionamento mesmo, um apoio. [...] família é GM5 complicado. É cada um por si e Deus por todos;

Considero todos os itens importantes (diálogo,

GM1

GM2

GM3

GM4

outros, mas o apoio é fundamental; 


\section{APÊNDICE 5 - Quadro 6 - Organização, Prioridades e a Qualidade do Tempo em Família}

\section{A ORGANIZAÇÃO DO COTIDIANO EM FAMÍLIA E AS PRIORIDADES}

Eu não organizo [...] Eu só vou levando. [...] Se eu quisesse daria para organizar melhor a minha vida. Mas não [...] Chego "em" casa, praticamente é um banho, faço a tarefa de casa com meu filho, fico um pouquinho, e vou dormir. É chegar "em" casa, é conversar com meu filho, perguntar como foi o dia dele. E como eu gerencio o meu tempo? É correndo pra casa e tentando fazer o que ainda dá tempo;

Tem mais ou menos uma rotina, mas não é nem questão de ser uma rotina organizada... Mais é devido aos horários mesmo. [...] em casa mesmo, eu procuro não fixar uma rotina assim [...] A rotina vai se adequando aos horários externos. [...] nada assim muito fechado [...] Primeiro a prioridade seriam os filhos, a necessidade dele, de dar comida, e fazer o dever de casa [...] e, depois, as outras coisas. Jornal. Mesmo a gente querendo fica pra segundo tempo. Marido, a gente tem que ir intercalando entre filhos e atenção também... [...] Então, é essa regra normalmente, primeiro a prioridade seriam os filhos. [...] e, depois, as outras coisas [...] fica pra segundo tempo;

Eu organizo mais ou menos. [...] Eu faço um esquema de todo dia um tem que fazer alguma coisa. [...] Tem uma tabelinha que eles me ajudam. Um leva a louça, estende a roupa. [...] a gente meio que se ajuda. O pesado sempre fica pra mim. [...] eles têm uma obrigaçãozinha também [...] Porque senão eu não dou conta. Não dou conta [...] à noite a gente se reúne [...] Aí a gente conversa como é que foi o dia de cada um;

Não. Acredito que já é uma coisa predeterminada assim. Como só mora eu, minha mãe e minha irmã, então a gente já tem uma rotina que ela meio que já se predeterminou com a convivência. Todo domingo eu tenho o compromisso (prioridade) de ir almoçar com meus avós. [...] Acho que é importante sim... A convivência, a vivência;

\section{QUALIDADE X QUANTIDADE}

DISCURSO

Embora todo o mundo fale que é qualidade, eu acho que a quantidade também conta, porque não adianta eu ter só meia hora, [...] Por mais que você aproveite, o tempo é pouco demais. E tinha que ter quantidade sim, porque é através da quantidade que a gente vai fazer a qualidade;

[...] Eu acho que é mais importante no momento que você está com eles, você dar atenção a eles. [...] você tem mesmo que se envolver no ambiente deles. [...] Quando você se dispõe a estar com eles é entrar mesmo, de mergulhar. Qualidade... Isso... É qualidade. [...] O importante é realmente você dar atenção;

Qualidade, né, sem dúvida. [...] É aproveitar bem. [...] Então aproveitar bem esses períodos que estamos juntos, porque estão ficando cada vez mais raros;

Qualidade sempre! Eu sempre prezo mais a qualidade.

GM1 quantitativo [...] ele incha, mas [...] não satisfaz; 
Eu acordo, aí vou assistir um jornal [...] Quando dá o horário, tomo meu café e venho "pro" banco. Cuido lá dos meus bichinhos, molho minhas plantas e venho "pro" banco. De noite eu chego "em" casa, me atiro no sofá, vou dormir. O que eu priorizo? Não tem como priorizar. [...] Se eu vir com alguma coisa priorizada na minha cabeça eu vou chegar de tarde frustrada porque eu não fiz. Entendeu? [...] Ah, eu não tenho compromisso com filho, com de dar comida pra ninguém. Sou só eu, e... É a vantagem de quem não tem filho, [...] eu vou fazendo as coisas à medida que elas vão acontecendo e vou resolvendo. Eu não tenho que ficar preocupada;

O meu dia é voltado para o trabalho e a família vejo bem pouco, já que moram há $230 \mathrm{k}$ de mim. Não posso dizer que tenho um cotidiano familiar, moro a muitos anos sozinha. Sinto muita falta e sempre que posso (nos feriados e férias) procuro estar próxima a eles.
Os dois, né? É tão bom quando você olha "pro" relógio ainda falta um dia pra acabar o final de semana... Ainda é sábado. [...] O problema meu é que eu não tenho compromisso... O meu único compromisso é de segunda a sexta aqui no banco. [...] Eu não tenho compromisso com ninguém; 


\section{APÊNDICE 6 - Quadro 7 - A mãe, a mulher, interferências, apoio familiar e bem-estar}

[...] Embora o tempo seja curto, eu me considero uma boa mãe... Preocupada com meu filho, [...] À noite sempre dou uma conversadinha com ele. [...] Eu, como mulher sou isso: sou mãe, sou profissional, sou dona de casa. Só;

A mãe sempre se sobrepõe a tudo. Sempre, sempre é primeiro mãe pra depois você pensar em seja qual for a outra coisa. Eu, pelo menos, eu, como mãe, eu sempre dou prioridade aos meus filhos. [...] você sempre pensa primeiro no lado materno para depois pensar nas outras coisas. Primeiro eles, depois as outras coisas;

A mãe é aquela protetora, que acha que os filhos nunca vão... Não crescem nunca. Mas assim, ao mesmo tempo que a gente tem aquele senso de proteção, tem que prepara-los para o mundo. [...] tem que se tornarem independentes. [...] a mulher... Sempre assim voltada pra melhorar sua performance, tanto profissional como... Como de esposa mesmo... De mãe.
Minha família, né? Mas é porque o banco é tão pesado! [...] a família interfere na vida pessoal. As decisões que a gente vai tomar, o que a gente vai fazer... A gente tá sempre pensando na família. Meu filho, apesar de ser tão pequenininho, ele... Acho que ele entende bastante... [...] Já o namorado, embora trabalhe no banco também, parece que não entende. [...] só o fato de eu "tá" em casa. [...] conversando com minha família [...] já me faz bem. Só estar com eles. Só a presença mesmo;

[...] a dificuldade maior é conciliar trabalho e casa... Não diariamente, mas, assim quando ocorre dos filhos ficarem doentes, [...] é aí que entra a família, né? [...] Porque quando você tem família próxima, sempre ajuda [...] Sempre tem alguém para te socorrer. Sempre apoiaram. [...] Até hoje ela (mãe) acolhe os netos. O marido também apoia [...] a gente divide. Uma família que é desunida não traz benefícios pra ninguém. E quando a família tem harmonia, é entrosada, se entende... $\mathrm{E}$ isso que eu procuro muito passar pros meus filhos. Eles têm que ser unidos [...] que família é união... Que família é isso, pra gente e 'pro' resto da vida. Quando você tem harmonia, quando existe amor, é importante [...] É um suporte para você levar pra vida fora bem;

O que mais interfere na pessoal? [...] Acho que é o tempo mesmo. [...] É esse tempo mesmo e recursos, porque eu tenho também que priorizar meus filhos. Eles apoiam... Mas assim, a gente sempre gostaria que o apoio fosse maior, né? Que houvesse um pouquinho mais de comprometimento, de 
Eu gostaria de ser lembrada como uma mãe que se dedicou, que amou mesmo seus filhos... Que buscou o melhor pra eles;

A mulher? [...] Eu sou uma pessoa equilibrada, mas também sou uma pessoa assim, bem sonhadora [...] Tenho muitos projetos e... Não consigo realizar todos eles [...] E sou uma pessoa determinada... Sou uma pessoa assim muito pacifista. Então, eu sempre "tou" querendo colocar as coisas meio que em ordem [...] Não consigo ver muita injustiça. [...] Essa sou eu assim. Sempre, tá sempre amiga [...] Eu prefiro pensar sempre no coletivo do que em mim mesma;

A 'mulher' é desejável [...] gosta das coisas certas, gosta... Faz o que pode e o que não pode... Trabalha... O que ela tem que fazer ela faz; ela assume compromisso. Ela briga com quem não assume [...] Ela se chateia com as coisas que estão acontecendo por aí. Com a falta de moral; falta de princípios... Falta de educação [...] Preocupada com o futuro, o amanhã;

(Definindo a mãe) A palavra que define a minha mãe é cuidado/zelo. compreensão. Mas, na medida do possível, eles apoiam sim. Os filhos. Não tanto quanto a gente gostaria. O que contribui é a gente ver que existe harmonia [...] Quando não existe conflito, [...] Não me sinto feliz quando a gente tem, às vezes, algum conflito [...] Aí fica aquela tensão;

Mais interfere na minha vida pessoal? [...] Eu não consegui definir se é esse caminho que eu "tou" aqui é o que realmente eu gostaria de "tar" [...] a gente tem um pouco um prazo de validade em algumas coisas. [...] Eu comecei assim... A me questionar um pouco sobre isso. [...] Isso "tá", realmente, interferindo na minha vida porque eu "tou" sem rumo. Minha mãe, minha irmã... Assim. Meus avós, né, tem que contar com eles [...] Sempre me apoiaram. [...] Eles me incentivam sim [...] se eu falar que vou jogar tudo "pro" alto... Que não vou querer mais nada disso, que eu vou embora... Vou morar um ano na Europa, minha mãe diz 'pode ir, vai';

Interfere na vida pessoal? Não, não deixo! [...] Tem certas coisas assim que eu ignoro, [...] eu tenho feito pedra. (Apoio) Sempre teve. [...] Sempre fui almoçar em casa [...] sempre teve o apoio dela (mãe); sempre... Sempre ajudou. O que ela podia ajudar assim [...] a facilitar. Ter minhas coisas do jeito que eu gosto (contribui para o bem-estar). Lá em casa eu boto as coisas tudo do jeito que eu gosto. Não tenho ninguém me chateando, me perturbando;

(O que mais interfere na vida pessoal) A exigência e o tempo gasto pelo trabalho acaba sugando grande parte da minha energia e dedicando cada vez menos a minha vida pessoal. Meu convício com a família é bem restrito, já que os vejo muito pouco. Mas o que possibilitou uma maior aproximação foi a minha transferência para Brasília, já que agora estou mais próxima e posso estar mais presente na vida deles e vice e versa. 


\section{APÊNDICE 7 - Quadro 8 - 0 Trabalho}

\section{SIGNIFICADO DO TRABALHO E SUA REPRESENTAÇÃO NA VIDA DAS GERENTES}

Tempo de trabalho no Banco: 9 anos.

Trabalho representa satisfação. Eu me sentir útil. [...] Não me imagino sem trabalhar. [...] Tem que ter trabalho pra gente se sentir útil. [...] "Tá" ligada no dia a dia... No que acontece. Acho que é bastante importante sim;

Tempo de trabalho no Banco: 7 anos

[...] quando estudante eu também trabalhei, [...] foi a primeira vez que eu ganhei dinheiro, com meu próprio suor... E foi uma fase importante que marcou a minha vida [...] gostei da coisa, me sentir importante de ganhar o meu próprio dinheiro. Eu acho que o trabalho em si, não só para mim, mas para todo o mundo é dignidade, né? Uma pessoa que não trabalha [...] eu acho que se ela não trabalhasse ela não se sentiria bem, [...]. Trabalho é importante pra você se sentir... Sentir bem, sentir que você é capaz de... De... De vencer desafios, de saber que você pode caminhar com suas próprias pernas, [...] eu acho que a pessoa que não trabalha não deve se sentir completa, porque o trabalho faz parte da vida do ser humano também, pra ele saber também que ele tem como se sustentar;

Tempo de trabalho no Banco: 6 anos

Olha, o trabalho representa um aspecto assim muito importante. Que através

\section{O PERFIL EXIGIDO E A ROTINA PROFISSIONAL}

DISCURSO

[...] o perfil principal aqui é o do atendimento ao cliente... De saber negociar, saber oferecer produtos do banco [...] que o cliente fica satisfeito, mas que a gente cumpra as metas do banco. [...] Eu acho que eu cumpro. (Quanto à rotina) Não sei se é possível não... Eu ainda acho que é impossível, porque é muita coisa. [...] é muito complicado planejar aqui [...] organizar aqui... Não dá não;

Eu acho que, plenamente, não. O meu cargo é um cargo de gerente estilo [...] o banco hoje ele é muito exigente em termos de metas [...] São clientes esclarecidos, não tem como você tentar convencer o cliente de comprar [...] você acaba meio que tendo que empurrar produto [...] Eu não sou muito teatro... Eu não tenho muito esse trejeito de enrolar, sabe? [...] fico meio que acanhada de me aproximar mais do cliente de uma forma que pra mim não é adequada. Eu acho que a pessoa tem que ser verdadeira [...] Isso eu não gosto. Isso não me faz bem. [..] acho que não "tou" muito adequada [...] Não tenho muito esse jogo de cintura não. (Com relação à rotina) Eu não consigo... Por mais que você tente. Você chega... Às vezes você chega "na" rua e pensa: vou fazer isso, aquilo, aquilo. Mas aí você acaba chegando no ambiente de trabalho e as coisas vão passando à frente e acaba que a rotina [...] Nunca acontece exatamente como ela deveria acontecer. Sempre uma surpresa... A gente 'tá' apagando incêndio sempre.

Eu tenho recebido bons feedbacks, né? Tanto de colegas quanto de clientes, como de superiores. É lógico que a gente 
do trabalho, né, que a gente se autoafirma. Que a gente é... Se sente valorizado. Eu me sinto bem quando o cliente fica satisfeito com 0 atendimento, quando você consegue também atender a expectativa do cliente. Eu gosto do trabalho com o público. O que eu não gosto muito é de você ter essa questão de muitas metas. [...] Fazer coisas assim além do que "tá" [...] na sua alçada. [...] E ser antiético. [...] Eu só não me identifico com essa questão de ter que... Essas metas que são meio que inatingíveis [...] Coisas que são factíveis, a gente corre atrás, a gente busca adequar;

Tempo de trabalho no Banco: 6 anos

[...] o trabalho como um todo, independente do que você exerce, ele é fundamental; [...] é batido, mas é o trabalho que dignifica o homem. [...] Eu não me imagino fazendo nada. [...] Não me vejo ociosa, obsoleta. [...] ele é fundamental, ele é necessário pra o caráter, desenvolvimento, enfim... Agora com esse trabalho que eu faço, eu vou dizer que, hoje, eu sou uma pessoa que [...] Estou desestimulada. [...] Tudo que eu podia dar aqui já foi sugado. [...] Com esse trabalho específico eu já "tou" meio desgastada

Tempo de trabalho no Banco: 31 anos

(O trabalho representa) Uma vida inteira dessa confusão. Eu sempre fui escrava do banco. 31 anos de escrava. Ah, eu já fiz tanta coisa nesse banco [...] Até água com balde eu já tirei desse banco, quando inundou lá no...;

Tempo de trabalho no Banco: 5 anos

O trabalho representa boa parte da minha vida, já que passo mais tempo trabalhando do que realizando qualquer outra atividade. "Me" identifico com sempre encontra deficiências. Eu sempre procuro preencher essas lacunas. Descobrir meus pontos fortes... Pra poder melhorar ainda mais, e tentar também descobrir meus pontos fracos pra tentar preencher esse espaco aí e dar uma melhorada na performance... Que a gente não é 100\% em tudo. [...] me considero preparada para o cargo. Eu até tento fazer uma rotina. [...] Mas nem sempre você consegue seguir isso aí, porque, às vezes, você tem que dar suporte em alguns setores. [...] Adequar à realidade. Então é flexível. Você tem uma certa rotina, mas essa rotina [...] Ela pode ser alterada no decorrer do dia;

[...] Eu acho que não somente eu, mas como um grande percentual de pessoas que trabalham nesse cargo que eu atuo tem um perfil elevado [...] Eu acho que é um pouco uma queima de talento. [...] ele não busca botar o funcionário naquilo que vai satisfazê-lo, mas busca só suprir vagas.. Independente se a pessoa tem ou não habilidade praquilo [...] quanto ao meu cargo, eu acho que eu tenho um nível elevado [...] Poderia "tar" exercendo "um" outro cargo que teria muito mais similaridade com o que eu tenho de formação. [...] Entrei no banco formada em economia, tenho pós-graduação em finanças... Tenho vários cursos nessa área. [...] Ele é um curso afim de qualquer área do banco. [...] O meu trabalho é rotineiro [...] como a gente atende cliente, a demanda sempre é diferente no dia a dia... Mas ela acaba sendo uma demanda diferente, mas meio que igual, né? [...] (a gente) acaba desenvolvendo uma forma que ele começa a ser rotineiro e igual todos os dias:

Olha, eu gosto do que eu faço! Só isso. Aqui não tem rotina, cara. Aqui você tem que resolver o que aparece, né? Como é que você faz uma rotina aqui dentro, dessa casa de doido aqui?

Atitude, responsabilidade, capacidade de iniciativa, assiduidade, comprometimento, conhecimento dos produtos e serviços da minha área de atuação entre outros. Considero 
boa parte do que faço, algumas atividades mais do que as outras, mas no geral a balança fica favorável. que correspondo de forma satisfatória o exigido pelo cargo.

Adoto "uma" certa rotina [...] costumo verificar algumas

atividades [...] analisar as mais urgentes e importantes antes

da abertura da agência. Mas no cargo que exerço lido com o

inesperado a todo momento. 


\section{APÊNDICE 8 - Quadro 9 - A Capacitação Profissional e o Convívio Social no Trabalho}

\section{IMPORTÂNCIA DA CAPACITAÇÃO PROFISSIONAL}

Eu acho que ainda falta melhorar. Porque o banco tem os cursos, treinamento, mas, muitas vezes, a gente "tá" com acúmulo de serviço e não pode sair pra fazer um curso. [...] Às vezes a gente quer fazer até alguma coisa fora do banco e também não tem tempo, não tem incentivo [...] Quer dizer, alguns cursos têm aqui... Mas a gente não é liberado pra fazer [...] Eles disponibilizam, mas não liberam [...] Para o meu trabalho aqui, eu acho que sim (é suficiente a capacitação atual), mas para eu pensar em crescimento, em outras coisas, eu acho que eu teria que procurar fora do banco;

O banco hoje tem uma forma de pontuar, meio que complicado, né? Porque é difícil você conseguir um padrão e aplicar esse padrão pra todas as pessoas. Mas, também não é fácil você encontrar a forma certa. Mas eu acho que "tá" indo, "tá" caminhando;

Qualificação acho que é importantíssimo... É uma coisa que eu busco muito. Que eu não me qualifico mais em função do cansaço. Às vezes chego "em" casa, ainda tem que estudar. Pra você ter uma ideia, eu já tenho cinco certificações! 'Tou' buscando mais [...] Embora às vezes a gente fica meio decepcionada, porque as coisas não acontecem como a gente gostaria... Mas eu sei que o processo é esse... O caminho é esse... É você estudar, você se qualificar, [...] Nunca é demais. [...] Que o profissional, se ele não se qualificar, ele vai ficando pra trás.

Ah, eu acho que ela é fundamental, né? Pra qualquer profissão, qualquer trabalho que você exerça [...] Acho que até o banco ele tenta... Eu acho que ainda falta mais... O banco tenta fazer capacitação [...] preparar o funcionário [...] Acho que agora ele "tá" enxergando isso muito mais. [...] Isso aqui não é

\section{O CONVÍVIO SOCIAL NO TRABALHO}

DISCURSO

Aqui... Em relação à amizade aqui, eu acho que o povo é mais distante. Em outra agência que eu trabalhei a gente era unido, tanto dentro com fora do banco. [...] Eu não sei se é porque aqui seja mais pesado, de repente. Acho que não... Acho que é o perfil das pessoas mesmo. [...] A gente se respeita, a gente conversa mais sobre o trabalho, compartilha o que tem pra fazer [...] Há ajuda aqui no nosso setor, mas o nosso relacionamento, realmente, é bem profissional;

[...] Aqui o grupo é coeso. Uma das coisas que eu gostei muito quando vim "praqui" é que senti que as pessoas são muito abertas a diálogo... Elas são colegas... Quando você tem uma dúvida... Isso é difícil no ambiente de trabalho. [...] Mas, graças a Deus, aqui, no espaço estilo, eu sinto que a coisa flui... Bem;

A convivência com a equipe de trabalho é muito boa. Eu tenho um relacionamento excelente com todos. A gente tem um relacionamento aberto. Quanto tem alguma coisa... Alguma coisa que o outro fez e não agradou, a gente sempre chama o colega e conversa entre a equipe mesmo. Então, a nossa equipe tem um clima muito bom... Muito, muito legal;

[...] Aqui eu encontrei assim... Mais apoio no sentido [...] de união, de forças [...] como um todo. [...] Aqui a gente tem... Tem bastante... É confiança e dinamismo aqui entre nós. Porque na realidade ninguém pensa só em si... Se um

GM1 
uma preparação só física. Ela também tem que ser bem trabalhada psicologicamente [...] saber trabalhar com terceiros, com prestação de serviços. [...] Eu sempre coloco entre a vida e o dinheiro... Eles (clientes) estão muito mais preocupados com o dinheiro;

[...] Eu acho que cada um faz a sua. Aquele que quer fazer, ele faz. Aquele que não quer fazer, não adianta você brigar, não adianta você reclamar [...] Isso eu acho que é de cada um. Isso parte de dentro da pessoa. É aquela velha história: ou ele é estudioso ou não é. Então, não adianta;

Necessária para crescimento de ambos (funcionário e empresa). descobre uma coisa, passa pra todo mundo... Todo mundo já faz igual. Então a gente pensa muito no coletivo. [...] Eu sou sempre pacificadora... Então eu "tou" sempre arrumando um eito das pessoas estarem bem. [...] Eu tenho essa coisa de liderança, mas não é aquela coisa de liderança forçada... Imposta [...] Liderança implícita [...] Isso acontece comigo em qualquer circunstância da vida... Seja trabalho, amizade, família... Eu sou meio que ponto chave da questão;

Depende... Depende do colega. [...] Tem uns aqui dentro que são pedra. [...] Tem uns aqui que você tem que se fazer de pedra porque senão, dá briga;

Prezo pela convivência com os meus colegas de trabalho e considero alguns mais próximos como amigos. Trabalho com uma excelente e unida equipe e há compartilhamento de ideias, pensamentos, emoções. Há comprometimento e colaboração entre os membros. Raramente, quando há divergências de objetivos e opiniões, sempre encontramos no diálogo o ponto de equilíbrio. 


\section{APÊNDICE 9 - Quadro 10 - Definição da Gerente, Reconhecimento e Interferências no Trabalho}

\section{A GERENTE E O RECONHECIMENTO DE SEU TRABALHO}

Bastante preocupada. [...] Ansiosa demais... Querendo resolver tudo pra ontem, o que me prejudica muitas vezes [...] eu acabo ficando nervosa e isso reflete em casa... Eu sou tranquila em relação ao atendimento, eu gosto do que eu faço, dos meus clientes. Apesar do sufoco, da dificuldade aqui, mas... De um modo geral, eu gosto de ser gerente... Precisava melhorar muita coisa, mas eu gosto.

O que é reconhecimento e aceitação? Bem, acho que caminham juntas, né? [...] É você ser visto, ser aceito [...] Com suas qualidades, e falhas... Com seus pensamentos, suas ideias. [...] Muitas vezes falta a gente ser reconhecida. A gente trabalha tanto... Tanto. A gente mal acaba um trabalho ou uma meta e vem outra. Às vezes nem é visto o que a gente fez... Tudo que foi feito, porque só pensa no próximo, em fazer mais e mais. [...] independente do que tem pra fazer, o que a gente tá fazendo ou já fez tem que ser reconhecido;

A gerente é mãe, é colega de trabalho, é amiga [...] Eu me considero assim, pau pra toda a obra. Eu consigo me moldar fácil ao ambiente... Não tenho inimigos, sou uma pessoa fácil de convivência e nunca tive problemas, assim em ambiente nenhum que eu frequentei. [...] Sempre soube entrar e sair bem dos lugares;

Reconhecimento é quando você dá o melhor de si, você consegue vencer aquele obstáculo que lhe foi proposto [...] E quem lhe propôs isso, ela é consciente, e de "uma" certa forma ela mostra pra você [...] Lhe agradece, né? Não é reconhecimento financeiro, nada. [...] E aceitação [...] Divergência sempre tem [...] O ser humano não tem como um ser igualzinho ao outro. Acho que a gente tem que ser tolerante e aprender a respeitar a opinião dos outros quando ela diverge da sua;

[...] É uma pessoa que se dedica ao que faz... Que busca melhora constante no seu desempenho... E que está sempre aberta ao diálogo. [...] busca atender ao máximo possível as expectativas, tanto dos superiores quanto dos

\section{INTERFERÊNCIAS NO TRABALHO}

Discurso

Eu acho que é só o trabalho... O próprio trabalho, o superior, as metas do banco, as regras, né? [...] Os normativos, que interferem bastante para o desenvolvimento do trabalho. De casa eu procuro não trazer não;

[...] Excesso de informações e cobrança. [...] O excesso de demanda diária, faz com que você acabe atropelando. Você mal concluiu uma coisa que lhe foi proposto, Ihe foi solicitado, e já tem outra coisa entrando em jogo;

[...] Eu vou falar do momento que eu "tou" vivenciando. O que "tá" mais interferindo é assim a quantidade de pessoas [... Como o nosso setor era pra ter uma quantidade maior, e agora

\section{GM1}


clientes, quanto dos colegas [...] Aceita críticas. [...] Eu não tenho problema algum em mudar, em melhorar, porque eu sempre busco melhorar a cada dia mais a minha performance, tanto profissional como pessoalmente [...] busco sempre aprender mais [...] e dar sempre o melhor de mim. (E) reconhecimento é que as pessoas percebam o esforço, a dedicação, o empenho que você tem no que você faz [...] Aceitação é meio que um sinônimo, né? [...] mas é você ser aceito no grupo [...] ter as suas ideias compartilhadas [...] As suas opiniões, mesmo que divergentes elas sejam aceitas pelos outros;

[...] Apesar, então, desse trabalho às vezes sugar forças [...] Eu vejo que eu tenho um dom, entre aspas, de trabalhar com pessoas Então, tenho bastante facilidade de trabalhar com pessoas [...] O que mata trabalhar em agência é a questão da pressão da meta versus a... Ao assédio moral [...]. Porque metas tem que ter. Se você tem metas na vida, por que não no trabalho? Mas eu acho que como ela the é imposta... Como Ihe é cobrado, [...] O que a gente sente mais assim... E o que às vezes causa uma depressão, um desânimo, um... Sabe? Um desespero. Acho que é a forma como lhe é cobrada.

[...] Na verdade, eu acho que reconhecimento é mais próprio do que do outro [...] Mais implícito do que explícito. [...] a partir do momento que você faz uma coisa e você é feliz naquilo que você realiza [...] isso vem de dentro pra fora e as pessoas enxergam isso e acabam reconhecendo aquilo que você faz. [...] Se você "tá" feliz e faz o que quer é porque, automaticamente, você se conhece e você se aceita [...] e você transparece isso pras pessoas [...] as pessoas [...] vão acabar te enxergando;

[...] Eu acho que eu gosto de fazer as coisas correta, dentro [...] das normas [...] da melhor forma possível, entendeu? Não gosto de... De prejudicar ninguém. Eu acho que quem trabalha comigo, por mais que eu brigue, que eu encrenque... Que me ache chata, [...] Uma vez eu recebi um elogio de um funcionário que [...] disse assim: "[...] Ela não deixa a gente fazer nada errado!" E, realmente, esse elogio [...] ele sempre foi corroborado, né, pelas auditorias que eu tinha [...].

Reconhecimento e aceitação? [...] particularmente, eu não fico esperando muito isso dos outros não. Eu acho que reconhecimento é eu "tar" com a minha consciência tranquila... Do serviço cumprido. [...] O que interessa é eu chegar "em" casa e saber que eu fiz o meu serviço, e fiz da melhora forma que eu pude fazer; em função da estratégia [...] a gente não tá com o setor completo [...] Às vezes você tem que sair do seu foco e atender o colega [...] Tem muito telefone que interfere. Acho que telefone interfere muito. Se eles conseguissem equalizar essa situação do telefone melhoraria muito a qualidade tanto do atendimento quanto do serviço em si.

[...] eu sou muito perfeccionista, metódica, e aqui no banco você não pode ser, porque nem sempre as coisas saem do jeito que você quer, ou seja, quase sempre não sai do jeito que você quer. [...] Então, aqui é mais complexo, porque as demandas, apesar de serem rotineiras, mas elas podem acontecer involuntariamente, de qualquer tipo;

O que mais interfere no meu trabalho? É as pessoas não fazerem as suas partes. Se cada um fizesse a sua parte não sobrecarregava um; 
Busco um elo de equilíbrio entre o que a empresa espera e o que o cliente necessita de forma que os objetivos de ambos sejam atingidos. Gerenciar é um desafio diário, e penso que o meu diferencial nesse sentido é conhecer tanto $\mathrm{o}$ aspecto negocial quanto o operacional. [...] Acredito que uma boa dose de sensibilidade, espírito de equipe, foco no cliente e conhecimento da política da empresa seja alguns dos ingredientes utilizados na atividade diária. (Reconhecimento) É ser valorizada e respeitada no que se faz. 


\section{APÊNDICE 10 - Quadro 11 - O Conflito}

Conflito é, [...] Eu querer fazer duas coisas e não dar, e elas não se cruzarem, ou se cruzarem erradamente. [...] fazer o trabalho de uma forma que o banco não permite por um normativo, também já é um conflito. [...] querer fazer uma academia e não poder é outro conflito, porque eu não tenho tempo. Muitas vezes é provocado por outra pessoa [...] mas a outra pessoa vai falar que é a gente. [...] a outra pessoa pode não aceitar as nossas ideias, nossas teorias e vice-versa. [...] Mas parte da gente também, por não "tar" disposta a mudar, a aceitar. [...] eu tenho melhorado muito [...] em aceitar a outra parte, a opinião, a ideia de outra pessoa;

Conflito é quando existem divergências de opiniões, ideias [...] E que não se chega a um denominador comum. Quando as pessoas não conseguem conciliar as diferentes formas de pensamento; $O$ conflito quando existe, existe de todos os lados, né? [...] É difícil você dizer que o conflito partiu de você ou se partiu da outra pessoa. [...] Da minha parte, eu sempre procuro parar, dar uma respirada funda. Mesmo achando que eu estou certa, eu sempre procuro me colocar no lugar da outra pessoa. [...] Que toda vez que você se coloca no lugar da outra pessoa, você aí, realmente muda;

A ideia de conflito é quando você quer fazer alguma coisa, você não consegue... Por " $n$ " razões muitas vezes... Não pela sua própria vontade. Quando há conflito [...] às vezes é provocado por mim, outras vezes pela outra pessoa. [...] Pode acontecer das duas formas. Eu acho. Essa divergência de ideias e interesses pode gerar o conflito;

[...] Minha ideia de conflito é tudo que está diverso à pacificação. [...] Acho que o conflito ele é necessário. [...] Pra se viver em um ambiente, seja ele qual for, você tem que ter um conflito, tem que ter ideias contrárias, até

Acho que, principalmente, divergência de ideias, né? Mais do que interesses, porque, muitas vezes, as pessoas têm os mesmos interesses, mas ideias diferentes, e daí uma parte não cede, e acaba gerando o conflito;

O que pode gerar o conflito é [...] falta de tolerância, quando as pessoas não tentam compreender o outro, né? Incompreensão [...] Individualismo, quando a pessoa pensa só no que é benéfico pra ela, mas não pensa que o benefício pra ela pode não ser para outra pessoa também;

[...] Às vezes o que é prioridade pra você não é prioridade pro outro. Às vezes o que é importante pra mim não é importante pro outro. Então você tem sempre que tentar o equilíbrio ali. Às vezes você tem que ceder em uma coisa, não ceder em outra porque também você tem que ter sua personalidade... Você não pode também ser só submissa. [...] Você tem que ter um meio termo;

Pra mim eu acho que isso tudo... Isso tudo vai existir sempre. Tipo: diversificação de pensamento porque cada um é criado de um jeito, cada um tem um pensamento... $E$ isso já é
GM1 
porque pra você chegar num denominador comum. Não tem como todo mundo ter uma ideia igual [...]. E acaba que você também não expandiria os seus conhecimentos [...] Então, acho que pra... O conflito é essencial. Claro que ponderado, né? Eu sou pacifista, mas [...] sou também bem opiniosa [...] Antigamente [...] eu tinha a minha opinião e as pessoas... Era difícil as pessoas mudarem essa opinião. [...] Hoje se você pegar uma opinião aqui, outra ali e colocar com a sua você pode chegar num denominador comum que seja melhor pra todos. [...] Geralmente eu "tou" é querendo fazer os conflitos acabarem;

[...] Olha, quer saber a minha opinião bem certa disso aí? Irmão que é irmão, que nasce da mesma barriga, toma o mesmo leite, tem o mesmo pai, a mesma mãe, dorme, mora na mesma casa, se matam! Imagina pessoas que vem de famílias diferentes, educação diferente, criação diferente, princípios diferentes, modos de pensar diferentes, não vão brigar? [...] Já imaginou a gente [...] tudo diferente, não vai ter um conflito? [...] "Ah, fulano não briga com ninguém". Realmente, ele não briga com ninguém, mas ele... Olha lá o Antônio [...] o tipo do cara que não briga com ninguém [...] Mas também o cara não existe. Outro dia eu entrei no mercado lá, eu "tava" a fim de brigar [...] Ah, tem dia que você "tá" a fim de brigar [...] Eu "tava" precisando dar uma relaxada;

Divergência de interesses, ponto de vista, objetivos. O conflito ocorre de várias maneiras, já que cada indivíduo possui seus princípios, conhecimentos, interesses, ponto de vista etc. O importante é o diálogo, e a partir daí encontrar um ponto de equilíbrio. intrínseco. [...] Mas o que eu acho que é essencial é a aceitação... [...] porque diferente todos nós somos. Então é o quanto você está disponível a aceitar a diferença do outro e o quanto você está maleável a, também, mudar um pouco [...] E o quanto você "tá" disponível a isso [...] a questão de melhorar alguma coisa, e [...] a aceitar do outro também;

Tudo... Tudo... O amor. Qualquer coisinha: o amor, um olhar. [...] Quando não gera conflito? Quando as pessoas se anulam, ou simplesmente deixam pra lá. Aquilo que eu falei no começo lá: desinteresse, as pessoas não querem saber de nada... "Tão"... Não "tão" nem aí pra o que "tá" acontecendo;

O conflito surge de algum problema e que não basta identificar de onde surgiu e sim focar na solução, até porque, com os conflitos sempre há oportunidade de reflexão e crescimento. 


\section{APÊNDICE 11 - Quadro 12 - O Conflito nas Relações Profissionais e Familiares}

Eu acho que existe uma grande cobrança primeiramente pela minha parte... Eu acho que o que me faz ficar nervosa com as metas sou eu mesmo. [...] Eu fico muito nervosa com as metas. [...] Eu sou uma pessoa assim perfeccionista, sou muito detalhista, chata até. Eu me cobro muito, [...] Mas também a chefia agora está cobrando bem mais que a anterior. Coisa que eu ainda "tou" me adaptando. [...] Só que, às vezes, eu acho que "tá" exagerando demais... "Tá" meio que tirando o sono da gente;

Muita cobrança... Ah, o chefe sempre, né? Quem sempre cobra é o chefe... E cobra muito;

Eu acho que eu me cobro mais [...] quando me comprometo, me proponho a fazer uma coisa, eu sou muito responsável... Assim, muito comprometida com o que eu me proponho a fazer. Eu me cobro mais;

Assim, num todo [...] numa relação de trabalho, eu sou a que me cobro mais. [...] Mas como eu disse: eu "tou" num determinado momento da minha vida que eu "tou" muito desanimada, então. Até desse desânimo eu me cobro. [...] Então, acho que a cobrança é minha mesmo. Mas, cobrança de superior a gente tem muito. Sempre tem... Todos os dias... Com certeza;

Quem me cobra? Quem fica me cobrando eu já cortei as asinhas, né? [...] Eu "tou" numa posição, aqui no banco, cômoda, entendeu? [...] Eu "tou" numa posição confortável [...] Eu procuro fazer (a minha parte), apesar de eu não ter mais necessidade de estar aqui [...] Se eu estou aqui, eu acho que eu
No caso marido, né? É com certeza. É ele que briga pra caramba... Muito, muito. [...] Por eu chegar um pouquinho mais tarde... [...] Por, às vezes, ele me telefonar aqui e eu não poder atender, porque "tava" atendendo um cliente [...] Ele não aceita não. Nem parece que trabalha na mesma empresa;

[...] Tanto os filhos como o marido também (cobram presença). [...] Mas, só que assim, ele (marido) percebe, né? [...] De querer, às vezes, ter um pouco mais de atenção... Mas percebe assim que a gente tá passando por uma das etapas de uma vida familiar;

Quem cobra mais? Olha, eu acho que os dois cobram (marido e filhos). A gente é cobrado pelos dois. Eu acho que [...] não tem um mais outro menos, não. Eu acho que é bem equilibrado;

[...] Minha vó cobra muito sim. Eu sou do mundo! [...] Eu tenho apego desapegado. [...] Agora lembrado: minha irmã e minha mãe, elas cobram muito, porque eu gosto muito de ficar sozinha. Porque às vezes eu chego "em" casa e quero ficar no meu quarto sozinha, e elas cobram... Querem que eu fique lá na sala com elas;;

Olha, lá em casa, o problema é que lá em casa todo mundo é resolvido. [...] Ninguém depende de ninguém. Olha, família, a melhor coisa que tem é família quando um não depende do outro. [...] Então não tem cobrança;
GM1 
tenho que ser profissional até o último minuto [...] Eu tenho que fazer as coisas do jeito que devem ser feitas;

No ambiente profissional a cobrança vem dos superiores, via de regra, mas Não moro com a família. temos dos colegas e de nós mesmo. 


\section{APÊNDICE 12 - Quadro 13 - O Trabalho interferindo nas Relações Familiares}

\section{VIDA PROFISSIONAL X VIDA PESSOAL}

[...] não costumo trazer de casa nenhum interferência. Ao contrário, eu levo do banco sim. Às vezes, até no fim de semana ainda tenho reflexo do trabalho [...] Às vezes eu durmo bastante no fim de semana... O tempo que poderia estar aproveitando. Embora eu acho que já melhorei bastante nos últimos tempos. Porque antes eu passava até o final de semana pensando naquela operação, naquele cliente que não deu certo, o que fazer para corrigir, o que vou fazer, como fazer... Agora eu melhorei muito. Pelo menos agora, fim de semana eu nem penso mais, eu procuro viver a minha vida em família. Mas eu ainda levo. Eu vou dormir, muitas vezes, preocupada, pensando nos assuntos do banco. Não desligo de jeito nenhum... Eu "tou" melhorando, mas ainda falta muito. [...] já deixei meu filho meio doentinho com a família para vir trabalhar... Coisa que hoje eu acho que não deve ser feito

Eu me desligo. "Me" desligo. Graças a Deus eu consigo isso. Passou ali... Exceto se for uma coisa muito grave, muito importante, que às vezes eu levo pra casa, pra trocar uma ideia com meu marido [...] Até porque quando eu chego "em" casa, os meninos estão numa fase de muita agitação. [...] Mas, hoje em dia, quando eu chego "em" casa acabou. [...] Eu corro riscos, né? Porque no trabalho, às vezes, você realmente tem que... Se você quer estar entre os cabeças e tal, você tem que realmente abdicar um pouco da tua vida familiar. [...] Mas eu não dou essa importância porque eu acho que a família também tem o seu lugar. Eu não posso desequilibrar as coisas. [...] Porque senão você não consegue administrar nem um lado nem o outro;

Esse é o problema! [...] Eu deveria desligar mesmo [...] Às vezes, quando me pego assim, trazendo do trabalho pra casa [...] quando eu percebo, eu já falo: vamos mudar de assunto. Não consigo (desligar do trabalho). Eu até tento... Tem um momento quando não "tá" tão estressante, o trabalho "tá"

\section{DEDICAÇÃO X COBRANÇA PELO SACRIFÍCO À VIDA DISCURSO} FAMILIAR

Embora eu esteja errada, eu acho... Preciso mudar, mas realmente eu me dedico mais ao trabalho. "Me" cobro bastante... Eu acho que tinha que dar um jeito [...] Eu podia ter chegado, de repente, mais cedo pra ir embora mais cedo. Não chegar mais tarde pra ir embora mais tarde. [...] Se eu chegasse mais cedo... E ir embora mais cedo e ter mais tempo pra família. [...] Eu, realmente, me cobro muito mesmo. Sacrifico muitas vezes (a vida pessoal);

Ah, dedicação... Cada um com seu horário de dedicação... Não tem... É equilibrado. Não sou aquela mãe que exagera, que passa o dia telefonando [...] $E$ também não sou aquela profissional que leva trabalho pra casa. De chegar "em" casa e não dar atenção à família. [...] Eu tento, tento dar uma equilibrada nas coisas;

A gente se dedica mais... O tempo maior é no trabalho. [...] No final de semana eu procuro estar mais com meus filhos mesmo. Mesmo no final de semana eu sempre pego um tempinho ali pra estudar... Pra mim. Tem que distribuir, tem 
mais distribuído [...] eu consigo até relaxar mais. Ultimamente, tem acontecido muito isso... Eu tenho acordado assim de madrugada e não consigo mais dormir; Porque assim, o cérebro fica trabalhando... Vem à tona. Se eu lembrar de uma coisinha só, aí parece que vem uma cadeia, uma sequência de coisas que surgem, você já não dorme mais. Resultado: você já passou o dia... Já começa trabalhar o dia cansada [...] Ultimamente tem acontecido muito isso." E complementa: "Ás vezes é complicado compatibilizar. De casa "pro" trabalho, às vezes [...] eu penso em pedir apoio pro meu marido, porque eu não quero interferir muito no trabalho [...] De qualquer maneira existe "uma" certa interferência, porque a gente não é um ser humano em casa e outro no trabalho [...] Eu tento conciliar sim.

[...] Até nas férias eu não me desligo muito [...] fico acessando o meu correio... Mando resposta pra cliente [...] Acho que é muito da personalidade. Quando você é muito metódica, perfeccionista, você não gosta de deixar nada pra trás ou nada pra ninguém fazer. Então tomo tudo pra mim. [...] eu acho que isso é um pouco complexo. [...] Me cobro... Ao trabalho não porque eu acho que passo muito tempo aqui. À minha família sim, porque aí eu tenho que pegar o tempo, o pouco que tenho com a família, ainda tenho que dividir com minhas outras coisas... Com a minha vida pessoal... Minha, minha mesmo. Eu acho que se eu tivesse que pegar um tempo, eu pegaria do trabalho pra colocar na minha família;

Ué, o trabalho faz parte do cotidiano! Você não sai daqui seis horas da tarde e desliga o botão. Não é assim. Quem faz... Quem diz isso, pra mim mente. [...] Ou então ele "tá" aqui e não "tá" aqui. [...] Por isso é que ele não faz o serviço dele direito, [...] Não desliga. Não tem cristão que desligue esse troço. [...] O cérebro é um só. [...] Porque se existisse isso [...] não precisava de psicólogo, não precisava de psiquiatra. $O$ cara não tinha trauma;

Nem sempre (me desligo), muitas vezes causa insônia e sensação de dever não cumprido. que planejar, tem que equilibrar bem o tempo, né? [...] ultimamente é mais o trabalho. "Me" cobro (pela falta de tempo). O tempo está curto pra atender as duas coisas. Então se eu tivesse assim um pouquinho mais. [...] eu poderia dedicar um pouco mais pros meus filhos... Pra família. [...] final de semana se você não se dedicar um pouquinho também a estudar, pra uma certificação, né? [...] Se você não faz isso em casa, aqui no trabalho não tem como você fazer. Porque aqui no banco é difícil. Esses cursinhos mesmo internos... Dificilmente eu consigo fazer um, porque a gente foca tanto [...] Se envolve tanto com [...] seu trabalho. [...] não dá mais tempo;

Eu me dedico à minha família, mas eu... Na verdade eu não me dedico nem a um nem a outro, porque eu tenho uma terceira coisa que eu faço. [...] Acho que eu equilibro um pouco de cada. [...] Não consigo me dedicar a uma coisa só [...] porque não tem jeito. Acho que todo mundo, né? (sacrifica a vida pessoal) Acho que não é só eu não... Acho que isso acontece. É fato consumado. É claro que se a gente tivesse que escolher quanto tempo trabalhar por dia, e quanto tempo dedicar a si próprio, à família, você, com certeza, você iria reduzir o seu tempo de trabalho, né?

Depende do que eu "teja" fazendo em alguma das partes. [... do que me requer mais a atenção. [...] Eu não tenho esse tipo de cobrança, porque... Como eu moro sozinha, né?

(Me dedico mais) ao trabalho. Às vezes me cobro. (Em algum momento) sacrifica a vida pessoal em favor da profissional 


\section{APÊNDICE 13 - Quadro 14 - Satisfação Pessoal e Administração do Conflito}

È minha família estar bem. Principalmente meu filho estar bem. A coisa que eu mais me preocupo... Que eu quero mesmo de verdade, é que meu filho... Que ele esteja bem... E, depois vem, é claro, o profissional. Mas, primeiramente a família;

O que mais me realiza é ser mãe. Eu sou mãe coruja. Sou mãe assim... Eu adoro ser mãe... E amo meus filhos assim muito... E o que eu puder fazer por eles, eu acho que vou fazer até a morte... Até;
Eu administro... Eu mesma, né? Parei pra pensar... Para mudar minhas ideias. A cobrança eu acho muito difícil. É uma coisa muito minha. É uma característica minha [...] E que ajustes? É que eu comecei a fazer terapia agora... Que vai ser uma ajuda [...] Porque sozinha eu não dou conta não, né? [...] Sozinha quase impossível;

Com o diálogo [...] $\mathrm{Na}$ família eu sempre procuro mostrar, mesmo pros pequenos: Olha, não dá porque a mamãe tem isso, tem aquilo... E no trabalho, às vezes você não consegue através do diálogo, porque 0 trabalho sempre te exige 0 máximo que você tem que dar de si... Mas aí o que acontece é que você não fica tão bem na foto [...] Mas, no fundo [...] eu acho que o chefe, não sei, se parar pra pensar... Não é tão ruim assim também. Você não é o melhor de todos... Mas a gente vai tentando levar;

[...] É eu me sentir aceita [...] Me sentir querida, sentir que eu sou importante pras pessoas [...] Que as coisas que eu faço são importantes pro outros... A qualidade do que eu faço [...] no trabalho também... Fazer um trabalho bem feito. Ser aceita no que faz, tanto no trabalho quanto pessoalmente. É aceitação mesmo

[...] Às vezes é complicado você compatibilizar. De casa por trabalho, às vezes [...] você tem que resolver algumas questões, por exemplo, de saúde. Ajuste seria mais assim... Fazer mesmo um planejamento mais adequado... Pegar os horários... Que às vezes você gasta tempo com coisa [...] que nem são tão importantes. Acho que é planejamento mesmo... É seguir aquela rotina... É flexível, né? Se surgir alguma coisa, um convite, você não vai também deixar de viver a sua vida pessoal pra ficar só focado em... Mas, acho que seria só isso. Acho que um planejamento mais adequado. E planejar melhor o tempo;

É cumprir uma tarefa... É chegar ao final de alguma coisa que eu planejei $[\ldots] \quad[\ldots]$ você acaba passando a maior parte do tempo, na verdade,
GM1 
se aqui eu planejei... Eu cumpri tanto de tal produto, e se eu fizer isso... Isso pra mim é uma coisa que me realiza. Isso dentro do trabalho [...] E na vida pessoal... É isso, só que no âmbito das relações pessoais, né? Eu acho que é conseguir ter um relacionamento bem sucedido... Com a família, com os amigos [...] Um relacionamento, enfim, amoroso também [...] É conseguir fazer dar certo... Que isso é difićlimo;

[...] Pra mim é serviço bem feito [...] é eu fazer uma coisa que eu... Que eu fique contente;

A realização pessoal só é possível quando há uma combinação feliz da vida profissional, social e pessoal. Estou em débito com algumas ainda para a realização ser plena. com essas pessoas que você trabalha [...] Se você contabilizar as horas, é no seu trabalho [...] (Família e Trabalho) meio que se cruzam nesse sentido, porque você acaba tendo uma relação meio familiar com as pessoas do seu trabalho e traz as pessoas da sua família pra esse convívio [...] Enfim, vai juntando e é tudo misturado. Eu sempre "tou" fazendo ajustes, mas nunca... Nunca dá certo $100 \%$, mas a gente vai levando conforme o tempo [...] Sempre faço concessões, né? Às vezes deixo um pra "tá" fazendo o outro [...] Gosto de pegar final de semana pra ir viajar. Mas aí eu tenho a banda da igreja pra tocar no domingo, eu tenho catequese pra olhar no sábado [...] eu tenho que arrumar alguém pra me substituir [...] pra poder viajar, e aí depois durante a semana à noite, que eu faço alguma coisa, eu deixo de fazer pra ficar em casa com a minha família [...] A gente vai sempre matando alguma coisa da rotina pra "tá" dirimindo aquela outra que você deixou de fazer antes [...] Eu sempre "'tou' matando" alguém;

[...] Eu não trabalho demais, não. Simplesmente eu retribuo o que o banco me paga dentro do meu horário. $\mathrm{O}$ banco me paga pra isso. O banco não me paga pra "mim" enrolar [...] O banco me paga pra eu trabalhar. Esse horário que eu fico aqui dentro eu trabalho. Só isso [...] Na hora que eu saio daqui não tenho que dar satisfação pra ninguém [...] Ora, na minha vida particular, os meus compromissos eu cumpro todos [...] Que se todo mundo pelo menos fizesse um [...] 2/3 ou 3/4 do que tem que fazer, eu acho que não sobrecarregava os outros;

Não há muito o que fazer, o trabalho é puxado e o melhor a fazer é adaptá-lo a outras necessidades, ou então priorizar caso não dê para conciliar de forma satisfatória. [...] moro só, então não há interferências nesse sentido. 